\title{
Study of the Damaging Earthquakes of 1911, 1999, and 2002 in the Murcia, Southeastern Spain, Region: Seismotectonic and Seismic-Risk Implications
}

\author{
by E. Buforn, B. Benito, C. Sanz de Galdeano, C. del Fresno, D. Muñoz, and I. Rodriguez
}

\begin{abstract}
A detailed study of four earthquakes that occurred in the Murcia region (southeastern Spain) in 1911, 1999, and 2002 has been carried out. New intensity maps have been plotted for the March and April 1911 shocks. These show maximum values of VII-VIII (EMS). We have found values of VI and V, respectively, for the 1999 and 2002 earthquakes. Surface wave magnitudes range from 5.2 for the Bullas 2002 event to 5.7 for the March 1911 event. Focal mechanisms for the Mula 1999 and Bullas 2002 events indicate reverse and strike slip motions, with scalar seismic moments of $5.9 \times 10^{16} \mathrm{~N} \mathrm{~m}$ and $8.6 \times 10^{15} \mathrm{~N} \mathrm{~m}$, respectively, and focal dimensions of 4.0 and $1.5 \mathrm{~km}$. Both earthquakes were recorded at epicentral distances greater than $21 \mathrm{~km}$, showing low values of peak ground acceleration (PGA) $(<0.020 \mathrm{~g})$. These records involve a ground motion less than the ones expected in the region, according to different hazard studies. The seismic hazard map that we obtained for the Murcia region (for a return period of 475 years) shows higher values than those given in the Spanish Building Code NCSE-02 (2002) (e.g., $0.24 \mathrm{~g}$ for PGA in the city of Murcia, compared with $0.16 \mathrm{~g}$ in the code).
\end{abstract}

\section{Introduction}

Southeastern Spain is a region of moderate seismic activity, where earthquakes of magnitudes above 5 are not frequent. For this reason, studies of these earthquakes are of particular importance; at a global level they may seem rather trivial, however, because they throw light on the active tectonics and the assessment of the seismic risk of the region. On 2 February 1999 a $M_{\mathrm{w}}=5.1$ magnitude earthquake occurred near the town of Mula (Murcia, southeastern Spain; Fig. 1, area C). This earthquake, despite its low magnitude, caused considerable damage in its epicentral area, with economic losses estimated at greater than 54 million euros. However, the Mula shock was not an isolated regional event. In 1911, two earthquakes occurred near the epicentral area of Mula, causing serious damage. More recently, on $6 \mathrm{Au}-$ gust 2002, another earthquake with $M_{\mathrm{w}}=4.6$ shook the town of Bullas, near Mula. The Murcia region (Fig. 1, area B), which includes all these shocks, has been considered a zone of moderate seismic hazard; the official Spanish seismic hazard map assigns values of $0.16 \mathrm{~g}$ to $0.04 \mathrm{~g}$, corresponding to excedence probabilities of $10 \%$ in 50 years (Spanish Building Code NCSE-02, 2002). The study of these shocks-including those of 1999 and 2002, which are among the few Spanish earthquakes with strong motion records-allows us to improve our knowledge of the seismic hazard in southeastern Spain and to check the acceletation values given in the Spanish Building Code NCSE-02 (2002) for this region. The interest of this work is focused on the fact that the Mula earthquake caused the highest damage reported recently in southeastern Spain since the large Torrevieja earthquake in 1829.

From historical seismicity, we know that in south Spain large earthquakes with maximum intensities of IX or X have occurred in the past (Fig. 2). The most recent large events occurring in this area were the 1829 Torrevieja and the 1884 Arenas del Rey earthquakes, both with maximum intensity of X (Muñoz et al., 1984; Muñoz and Udías, 1991). The Torrevieja event was located only $50 \mathrm{~km}$ to the east of the studied area. Other large historical events are located along the coast, where seven shocks with intensities equal to or greater than IX occurred between 1518 and 1884. In the Murcia region only two shocks had occurred, in 1579 and 1678 , before the two in 1911, which reached maximum intensities of VIII (Mézcua and Martínez Solares, 1983). Data for these shocks are very scarce, and their study is not included here.

The distribution of epicenters for the period 1980-2000 $(M \geq 3.0)$, taken from the Instituto Geográfico Nacional (IGN) data file, has been plotted in Figure 3, together with the most important geological faults. The most active seismic areas correspond to the Granada Basin $\left(\mathrm{GB}, 4.5^{\circ} \mathrm{W}\right)$, with frequent shocks of $m_{\mathrm{b}}=3$, and the area near the Almería coast (ALM), where a swarm occurred in 1993-1994 with two shocks of magnitude 5.0 (Rueda et al., 1996; Buforn et al., 2004). Most shocks have shallow foci (h $<40$ 


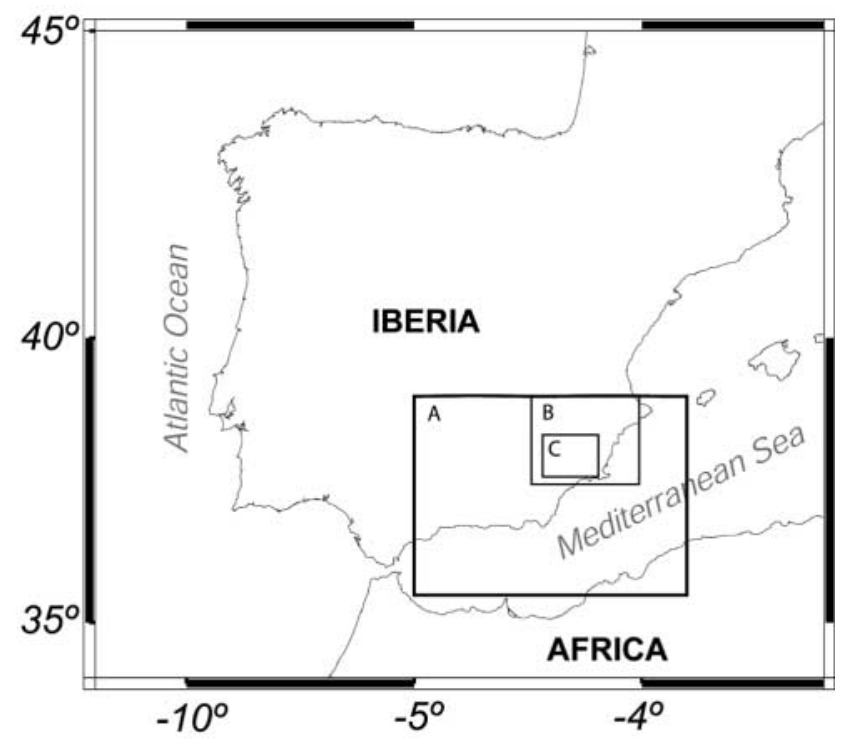

Figure 1. Geographical location of the Murcia region (southeastern Spain). Seismicity (A), focal mechanisms and main faults (B), and geology (C) of the marked areas are shown with more detail in Figures $2,3,4$, and 6 .

$\mathrm{km}$, black circles). However, at the western end of the region, at about longitude $4.5^{\circ} \mathrm{W}$ (around Málaga [MA]), an important distribution of earthquakes, approximately in the $\mathrm{N}-\mathrm{S}$ direction exists with foci of intermediate depth $(40<$ h < 150 km; Buforn et al., 1991, 1997; Morales et al., 1999). The seismic activity decreases to the northeast and the region where the earthquakes we have studied occurred (marked area) have not been very active in the last 20 years.

\section{Geological Setting}

The southeastern area of Spain corresponds to the eastern part of the Betic Cordillera. It is formed by two main domains: the Internal Zone and the External Zone. The Internal Zone is formed by three tectonic complexes which are, from bottom to top, the Nevado-Filabride, the Alpujarride and the Malaguide (also the Dorsal, usually linked with the Malaguide; Fig. 4). The Nevado-Filabride and Alpujarride complexes are formed mainly by Paleozoic to Triassic metasediments, metamorphosed and deformed in the Alpine Orogeny. The Malaguide complex is formed by Paleozoic to Tertiary sediments. The External Zone corresponds to the Subbetic and Prebetic domains, with Mesozoic and Tertiary sediments overlying a Hercynian basement, which is situated at variable depth, usually about 5-7 km, never outcropping and only known from geophysical data. In many points over the External and Internal zones there are Neogene and Quaternary sediments, forming several important post-orogenic basins.

The Betic Cordillera developed during the Tertiary, forming the present contact between the Internal Zone and the External Zone in the Early Miocene, particularly during the Burdigalian. After this epoch other deformations occurred and important faults of different character appeared. The longer line of faults corresponds to the Cadiz-Crevillente-Alicante fault system (CA, Fig. 3; Sanz de Galdeano, 1983 ) with a general trend varying from $60^{\circ} \mathrm{N}-70^{\circ} \mathrm{E}$ to eastwest. This system is situated within the External Zone, but near the contact with the Internal Zone, or in coincidence with this contact, as happens precisely in the area of Mula. This system usually shows right-lateral displacement. Other important faults are the Murcia-Carrascoy, AlcantarillaLorca (Fig. 4), and Palomares and Carboneras faults (PC, Fig. 3). These have north-northeast-south-southwest to northeast-southwest trends, are predominantly left-lateral strike-slip, and control much of the structure of the Almería and Murcia provinces. Other northeast-southwest striking faults occur, usually with right-lateral displacement, in the Granada sector, but also near Málaga, Murcia, and at other points of the Betic Cordillera (Fig. 3).

Figure 4 shows the most important geological features of the Murcia area. Here only the Alpujarride and Malaguide complexes outcrop, although the Nevado-Filabride Complex is probably under these complexes. The External Zone is represented by its two domains, the Subbetic and the Prebetic. One of the most outstanding geologic features of this area is the contact between the Internal and External zones, partially hidden by Neogene and Quaternary sediments. This contact is not straight in this region. Generally it trends in a $\mathrm{N} 70^{\circ} \mathrm{E}$ to east direction, while, near the western border of the Mula-Sierra Espuña area, its trend is approximately north-northeast-south-southwest. This contact was formed during the western displacement of the Internal Zone, during the Early Miocene, and the present geometry of the region indicates that the External Zone overthrusts the Internal Zone. The north-northeast-south-southwest folds and faults to the south of Bullas were formed during the stage of the formation of this contact.

Several of the faults we have previously mentionedthe Murcia-Carrascoy faults, the Alcantarilla-Lorca, and the Crevillente fault-lie in this region (Fig. 4); in a northwestsoutheast direction, are the Lower Segura fault (from Abarán to Murcia) and the Socovos fault (here near Calasparra). We are concerned mainly with the Lower Segura and the Crevillente faults because they are probably responsible for the first of the 1911 earthquakes and the second of the Mula and Bullas shocks.

The Crevillente fault (or the Cadiz-Alicante fault system) really corresponds to numerous faults with a general trend in a $\mathrm{N} 70^{\circ} \mathrm{E}$ to east direction, forming in many sectors a zone 0-20 km wide covered by parallel faults. From Bullas-Mula to the east, the main line of the Crevillente fault system coincides with the contact with the Internal and External zones. Their most important movement occurred during the Early and Middle Miocene; regional and microtectonic data show that these faults moved usually with right-lateral strike-slip. Faults with vertical motion, reverse 


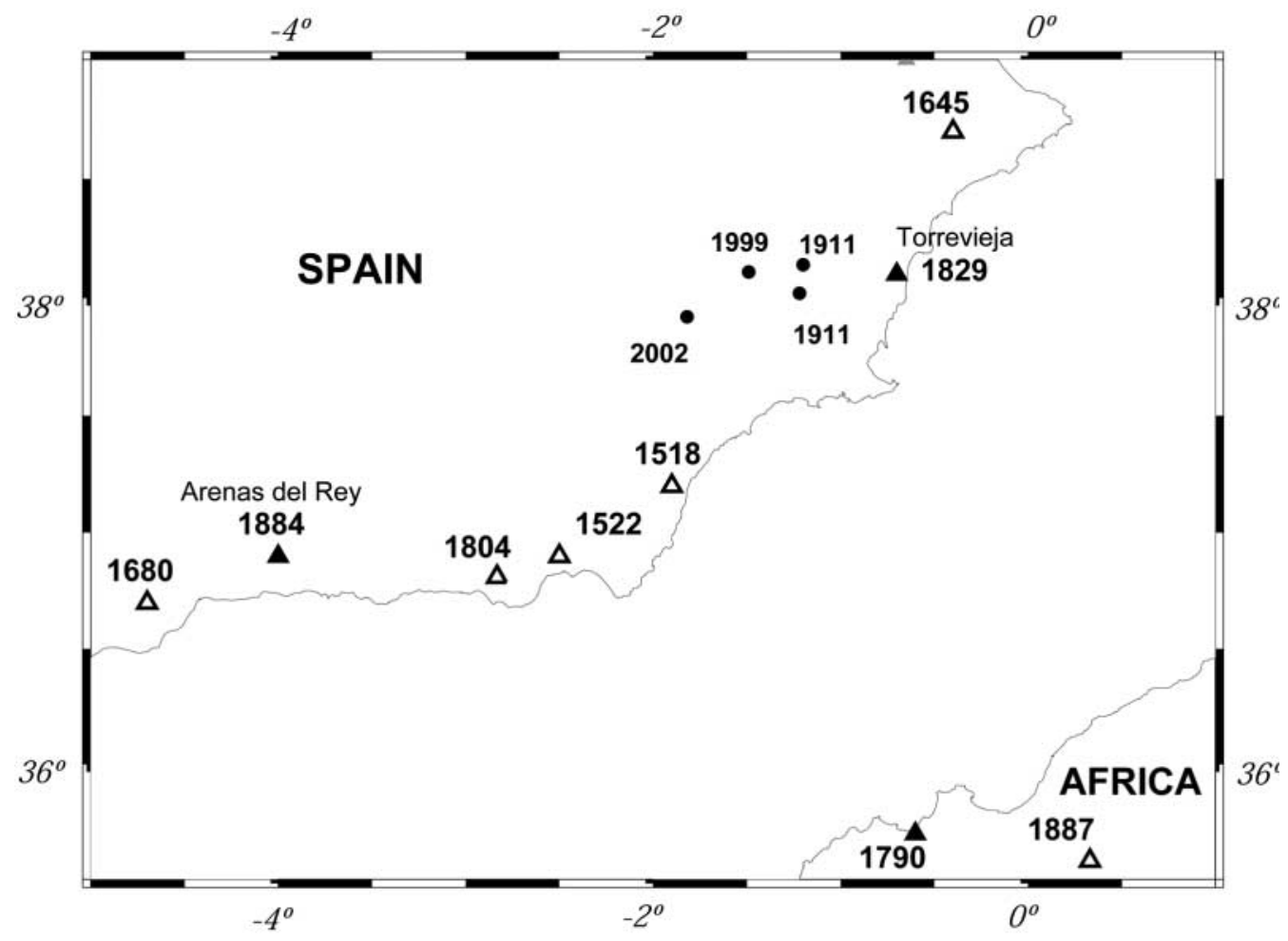

Figure 2. Distribution of earthquakes with maximum intensity greater than $\mathrm{X}$ (black triangle) or IX (white triangle) in southeastern Spain (same region as shown in [A] in Fig. 1). Epicenters of the 1911, 1999, and 2002 earthquakes are shown as circles. Sizes of symbols are proportional to the intensities.

or normal, are also present. Especially for Pliocene and Quaternary times, some left-lateral displacements have been recorded, probably owing to changes in the regional stress direction.

Regionally less important is the Lower Segura fault. It has a northwest-southeast strike and is right-lateral strikeslip. It also shows young (Late Miocene to Quaternary) movement.

\section{The 1911 Earthquakes}

On 21 March 1911, an earthquake occurred near Torres de Cotillas, causing serious damage in this town and in the surrounding villages in the Murcia region (Figs. 4 and 5a). This earthquake was followed by numerous aftershocks. On 3 April, another earthquake, of similar size, occurred near Lorquí (near Torres de Cotillas; Figs. 4 and 5b). This earthquake was also followed by aftershocks, which extended the seismic period till 24 May. The times and epicentral coordinates of these two earthquakes are from Mézcua and Martínez Solares, (1983; Table 1).

These earthquakes have been the subject of several reports (Jimenez de Cisneros, 1911; Sánchez NavarroNeumann, 1911, 1912, 1917, 1920; Sánchez Lozano and Marín, 1912; Galbís, 1932; Rey Pastor, 1936). The March earthquake was studied by Rey Pastor (1936), who plotted the intensity map, giving a maximum value of VIII (ForelMercalli scale). However, for the April event, no intensity map was made. We have collected contemporary published data on the effects of these earthquakes from local archives, seismological literature, and newspapers and, using this information, have reevaluated the damage and plotted new intensity maps (Figs. 5a and 5b; our references are shown in the Appendix).

The report of Sánchez Lozano and Marín (1912) presented a detailed description of the effects of the earthquakes on buildings, together with a collection of photos. Using this information, we have evaluated and classified the quality of buildings. From the same report, we estimated that most of the houses corresponded to vulnerability class $\mathrm{A}$ on the $\mathrm{Eu}$ ropean Macroseismic Scale 1998 (EMS-98) scale (rubble stone, fieldstone, and adobe). We considered only three buildings - the Lorquí Church, the Palace of Duke of Pastrana (Cotillas), and the Monastery of San Jerónimo (Guadalupe) - as class B (simple stone, unreinforced with manufactured stone units). In order to assign the value of intensity, we took into account the number of buildings damaged in every village. We did this to avoid extreme observations that might have overestimated the intensity. For example, for the March event, we did not evaluate the intensity for the village of Ceutí because only one house was damaged. 


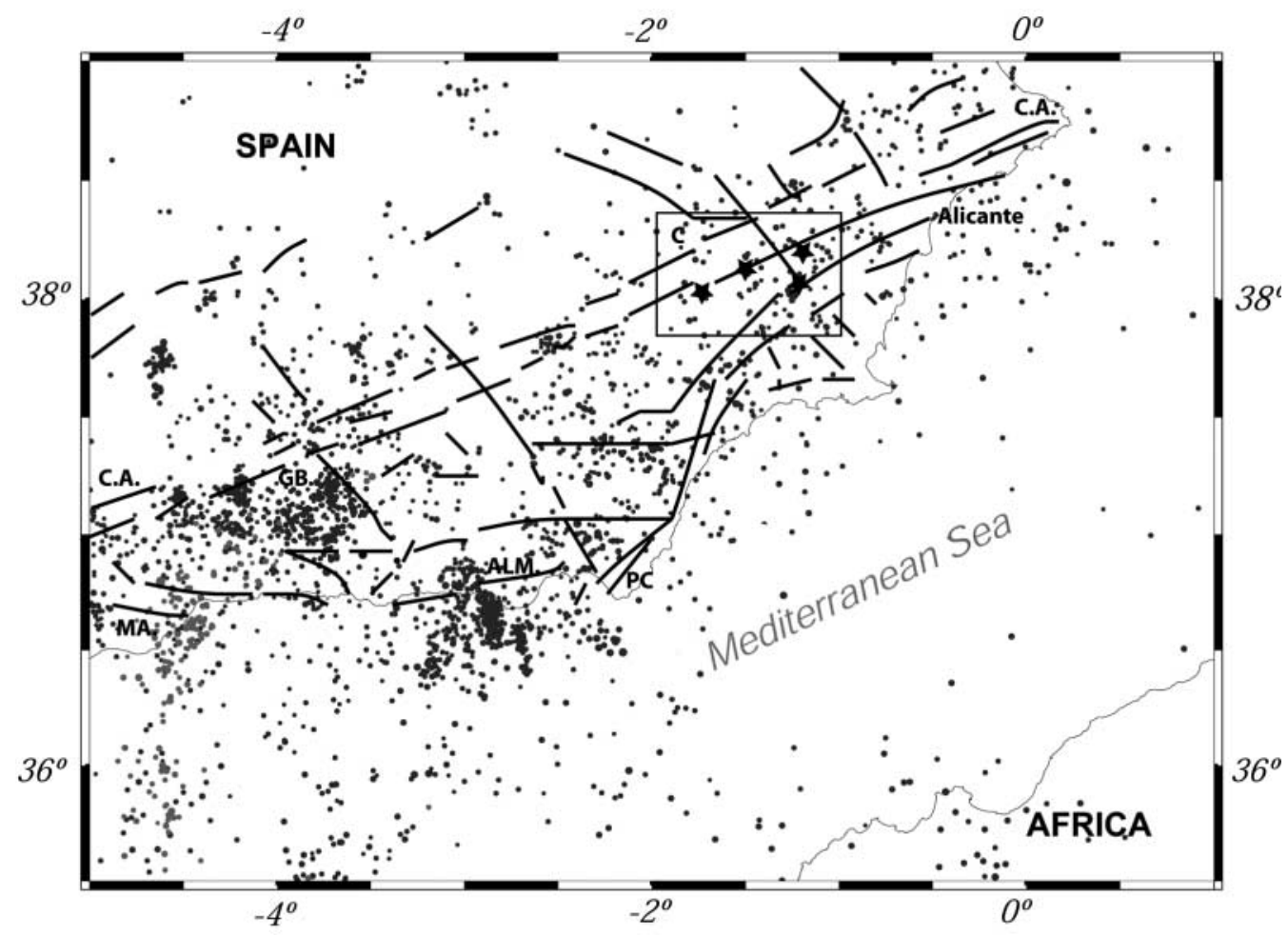

Figure 3. Seismicity map for southeastern Spain (same region as shown in $[\mathrm{A}]$ in Fig. 1) for the period 1980-2000 $(M>3.0)$ taken from the IGN data file shown with the most important geological faults. Shallow earthquakes $(\mathrm{h}<40 \mathrm{~km})$ are shown as black circles and intermediate depth shocks as gray circles. Stars correspond to the earthquakes studied in this article. CA, Cádiz-Alicante fault system; PC, PalomaresCarboneras fault; MA, Málaga; GB, Granada basin; ALM, Almería.

The maximum intensity (VII-VIII; EMS) for the March event occurred in Torres de Cotillas, Campos del Río, Alguazas, and Lorquí (Fig. 5a). We summarize the damage in these towns as follows. In Torres de Cotillas, four houses were completely destroyed, and the Palace of Pastrana was seriously damaged. In Alguazas, three houses collapsed; the church, the school, and other houses were seriously damaged, and many chimneys fell down. In Campos del Río, the church fell down, the school, the church tower, and the priest's house were seriously damaged, and there was damage in most buildings. In Lorquí, there were cracks in many buildings and walls, as well as moderate damage in most houses, and cracks in the church and tower. It is difficult to compare our intensity map with those of Rey Pastor (1936) owing to the different intensities scales used (i.e., ForelMercalli in the Rey Pastor study and the EMS in this paper). Furthermore, in the Rey Pastor map, intensity was not assigned to Campos del Río, probably owing to the lack of information for this location.

The intensity map for the April earthquake is shown in Figure 5b. The maximum intensity (VIII, EMS) is given in Lorquí. Here most buildings suffered moderate to serious damage. Most people were frightened; the cracks in the church from the March event were increased, its tower was seriously damaged, two people were injured, many houses had to be abandoned, and part of the population had to be put into army huts and tents. However, much of the serious damage in this town was duc to the fact that most buildings were already damaged in the March earthquake (intensity VII-VIII in Lorquí). Thus, we may have probably overestimated the intensity value of VIII for the April event. In Alguazas, Torres de Cotillas, and Campos del Rio, we have estimated lower values of intensity (V-VI, compared to VIIVIII for the March event).

The March and April earthquakes were recorded at three seismic stations in Spain; Cartuja (CRT), Ebro (EBR), and Toledo (TOL). Cartuja had a Bifilar Cartuja seismograph (an instrument of their own manufacture, similar to a horizontal Vicentini); Toledo, a horizontal Wiechert seismograph; and Ebro, Vicentini instruments with three components (Batlló, 2000). The magnifications were between 90 (for the Vicentini horizontal components) and 200 (for the Wiechert). We have used these records to estimate surface wave magnitudes, using the 1964 IASPEI formula previously used by Badal et al. (2000) to estimate the magnitude of early instrumental Iberian earthquakes. Values obtained are $5.7 \pm$ 0.5 and $5.3 \pm 0.3$ for the March and April events, respectively.

A problem in the study of 1911 earthquakes has been to separate the effects of the April event from those of the 


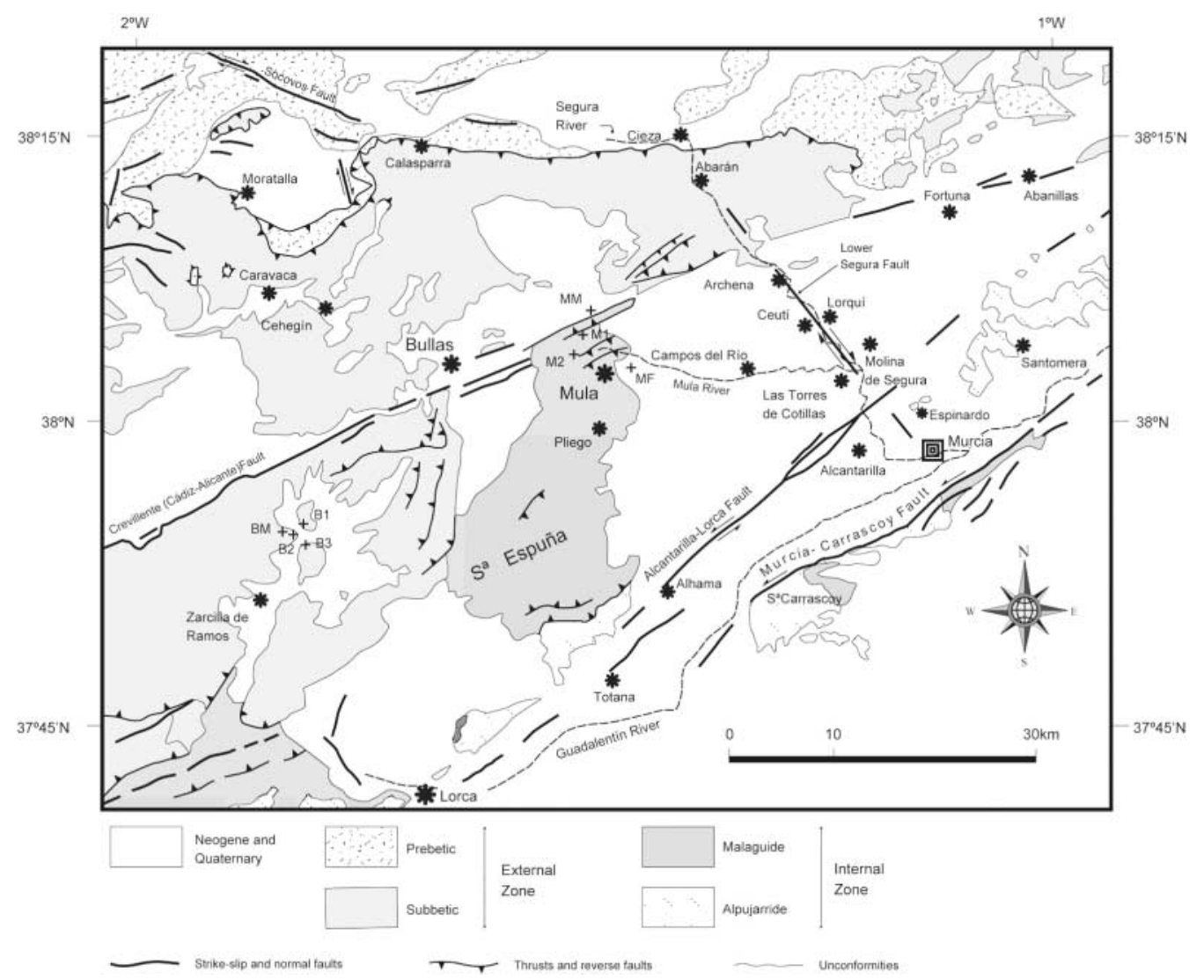

Figure 4. Details of the main geological features for the studied region (same region as shown in $\mathrm{C}$ in Figs. 1 and 3) together with the location of epicenters for the Mula (MF, MM, M1, and M2) and the Bullas (BM, B1, B2, and B3) earthquake series.

March event. Owing to the proximity in time, it was difficult for us to know if the damage suffered in some buildings and houses in the April event was due to this shock, or if they had been affected previously (i.e., by the March earthquake). Our maximum intensity for the March event (VII-VIII, EMS) is lower than our value obtained for the April event (VIII, EMS). From instrumental records we observe that the magnitude of the second shock (5.3) is lower than that of the first event (5.7), although we have obtained a higher intensity for the April earthquake. In the IGN Data File (IGN, 1999), both earthquakes were assigned an intensity of VIII Medvedev, Sponheuer, Karnik scale (MSK), similar to what we had obtained.

After the 1911 series, no important seismic activity occurred in the Murcia region, except an earthquake on 23 June 1948. This shock was located about $60 \mathrm{~km}$ west of the 1911 series, with the time, coordinates and magnitude given by the Spanish Ground Motion Network (IGN) as 03:43:55.0 coordinated universal time (UTC), $38.142^{\circ} \mathrm{N}, 1.758^{\circ} \mathrm{W}$, and magnitude 5.0. According to Rey Pastor (1949), the maximum intensity was VIII (Forel-Mercalli). Badal et al. (2000) determined a magnitude of 5.3. For this earthquake, we have been unable to find new information and, consequently, unable to reevaluate the intensity.
The Mula 1999 and the Bullas 2002 Earthquakes

The Murcia region was seismically very quiet until 2 February 1999, when an earthquake with $m_{\mathrm{b}} 5.5$ (IGN) occurred near the town of Mula (Fig. 2; Table 2). This shock was preceded by a foreshock occurring 20 minutes before, and was followed by many aftershocks, two with magnitudes greater than 3.5. The main shock has been the subject of several studies (IGN, 1999; Buforn and Sanz de Galdeano, 2001; Mancilla et al., 2002; Martínez-Díaz et al., 2002).

In August 2002, another earthquake with $m_{\mathrm{b}} 5.5$ (IGN) occurred near the town of Bullas, $40 \mathrm{~km}$ west of Mula (Fig. 2). The Bullas earthquake was also followed by many aftershocks, three with magnitudes greater than 3.0. The Bullas series was recorded by a temporary broadband network formed by 10 stations installed in southern Spain and northern Africa (Buforn et al., 2002). We have used this network, together with the records of the IGN Seismographic Network and other permanent networks in the region, to relocate the Bullas main shock and the three larger aftershocks using the HYPOINVERSE2000 program (Klein, 2000) with the detailed crustal model of Dañobeitia et al. (1998). We give the origin times, hypocentral coordinates, and magnitudes $\left(m_{\mathrm{b}}\right)$ for the foreshock, main shocks, and aftershocks of the Mula and Bullas earthquake series in Table 2. 


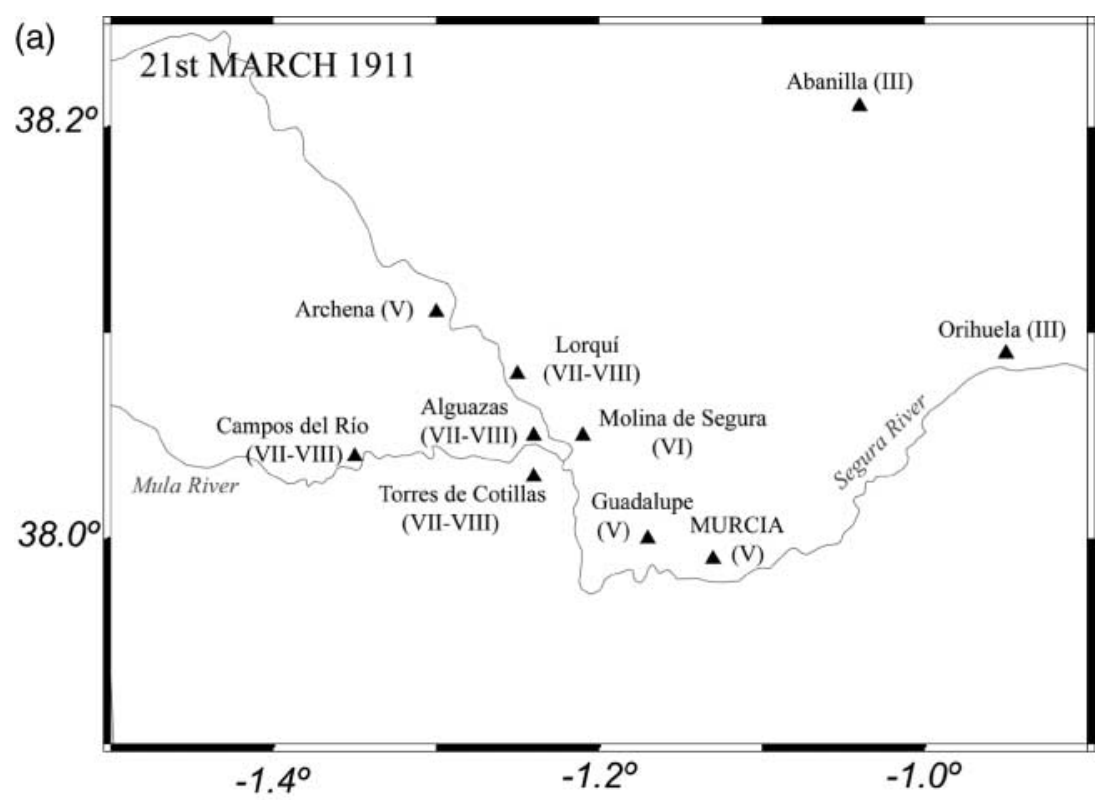

Figure 5. Intensity maps for the March 1911 (a), April 1911 (b), 1999 (c), and 2002 (d) earthquakes. Campos del Río is represented by a star in $5 \mathrm{c}$. (continued)

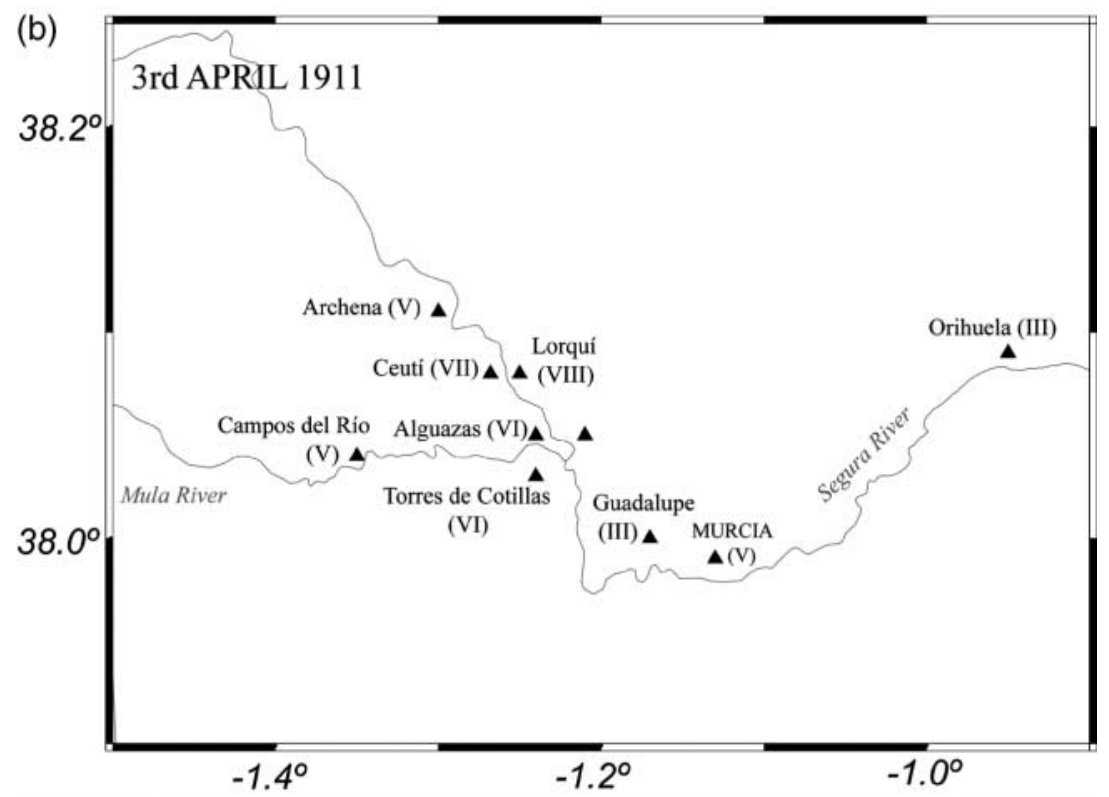

The hypocentral coordinates obtained in this study are very similar to those obtained by the IGN. For both solutions, there is an azimuthal gap of about $100^{\circ}$ in the distribution of stations, owing to the lack of stations east of the epicenter. In general, the root mean square (RMS) errors obtained in our determination are lower than those obtained by IGN: $0.68,073,0.62$ and $0.69 \mathrm{sec}$ versus $0.85,071,0.82$ and 0.96 sec. Both sequences correspond to very shallow earthquakes, with depths less than $5 \mathrm{~km}$ for the Mula shocks (only the foreshock has a greater depth, $7 \mathrm{~km}$ ) and in the range 5-11 $\mathrm{km}$ for the Bullas shocks (Table 2). We were unable to relocate the 1911 earthquakes because only three seismograms were available and it has been impossible to find other records.
Intensities for the Mula and Bullas main shocks taken from the IGN web page (www.geo.ign.es, last accessed January 2004) are plotted in Figures 5c and 5d. For the Mula event, a maximum intensity of VI (EMS) was reached in Mula, Torres de Cotillas, Campos del Río (marked with a star in the map), and in other towns along the Mula river. This earthquake was felt as far away as Madrid (400 km). For the Bullas shock, a maximum intensity of V (EMS) was reached in Bullas, Cehegín, and in other towns. For the Mula and Bullas aftershocks, the maximum intensities were III for Mula and IV for Bullas.

In comparing the 1911 with the 1999 and 2002 earthquakes, we see that the intensities for the Mula and Bullas earthquakes are lower, with maximum values of VI (EMS) 


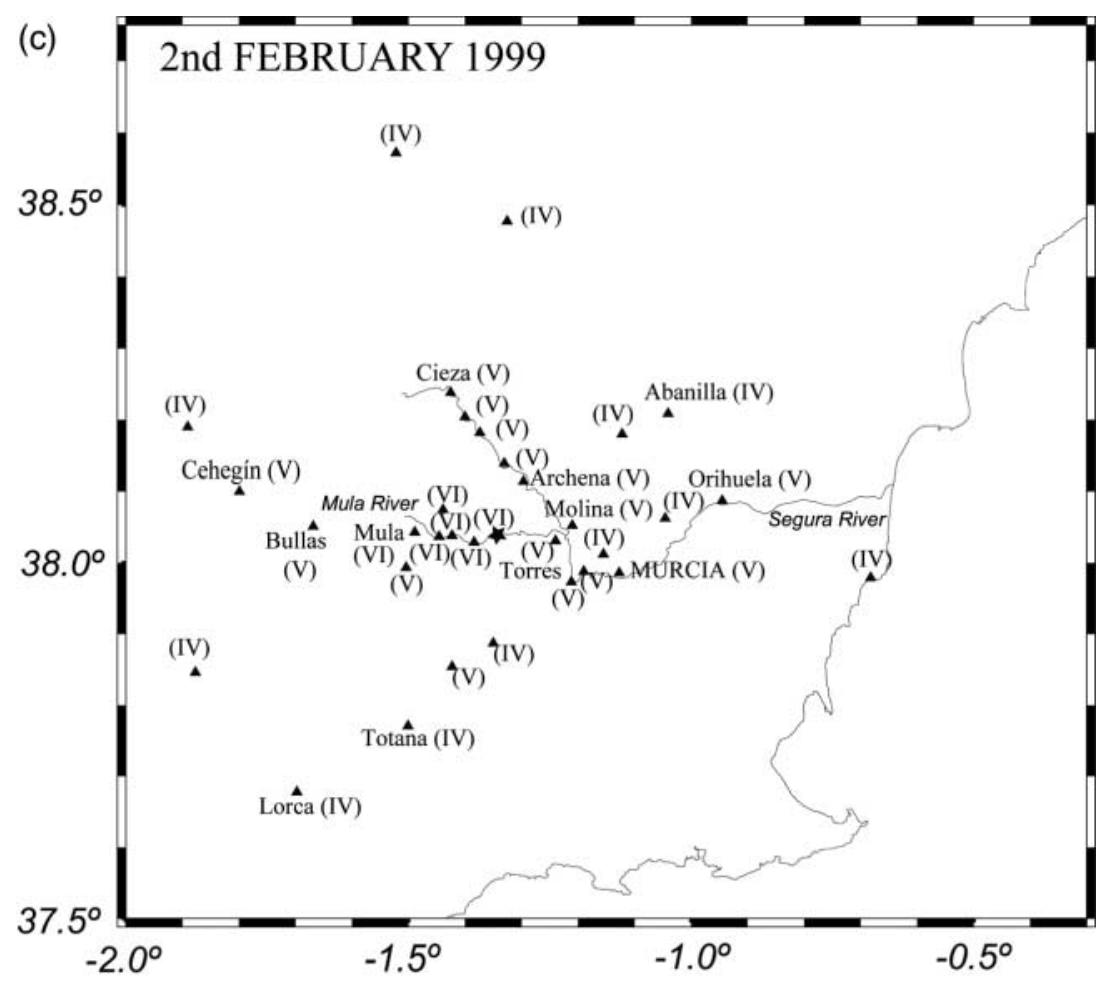

Figure 5. Continued.

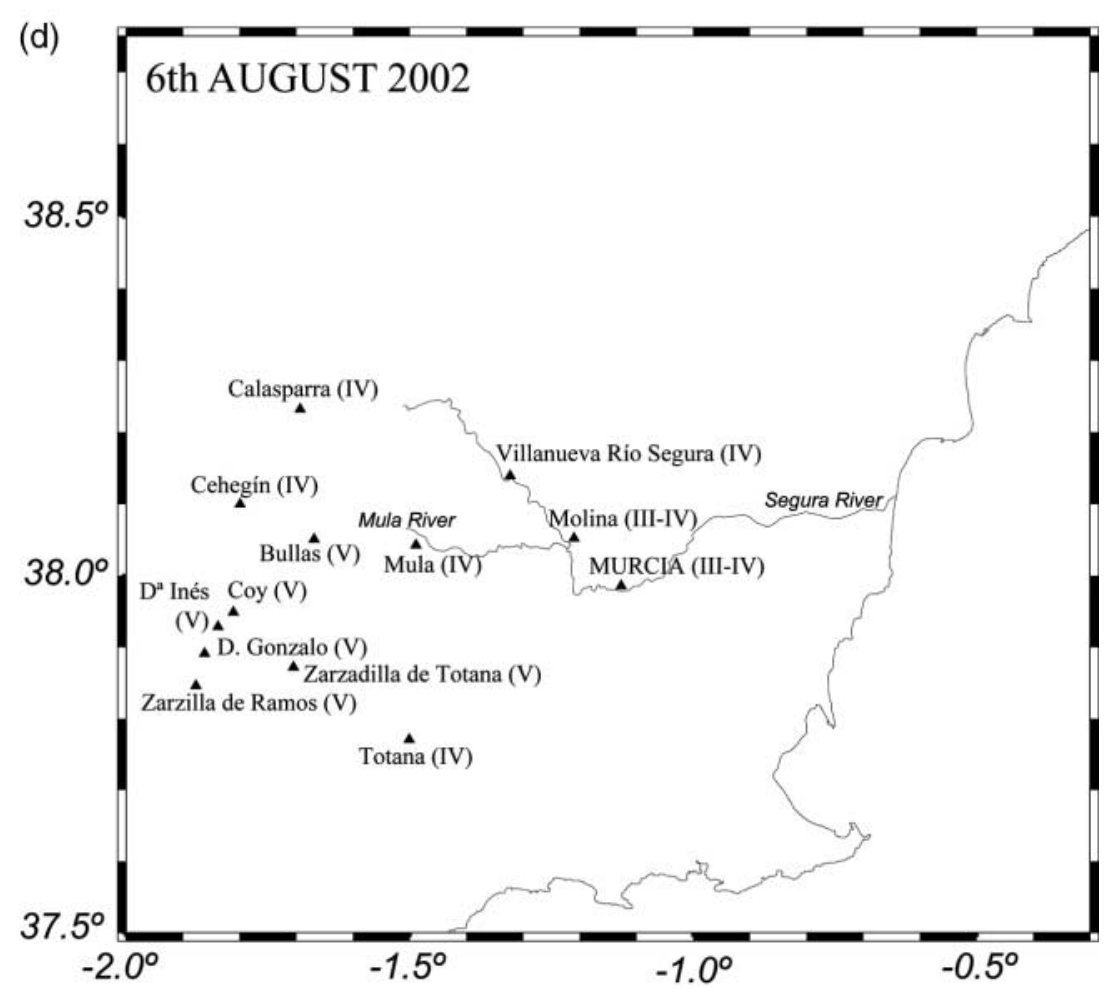

and V (EMS), respectively, versus VII-VIII (EMS) for the 1911 earthquakes. For example, the intensity in Campos del Río was VI (1999 event) versus VII-VIII for the March 1911 shock. Torres de Cotillas showed a maximum intensity of $\mathrm{V}$ for the Mula event and VII-VIII for the March 1911 shock. From Figure 5, we can see that maximum intensities were reached in the towns along the Mula River (VII-VIII in March, 1911 and VI in 1999). These values can be explained by soil amplification along the Mula river. The Bullas epicenter is located $30 \mathrm{~km}$ east of the Mula river, thus this effect has not been observed.

The Mula main shock (MM) has same magnitude $\left(m_{\mathrm{b}}\right.$ 
Table 1

Times and Coordinates of the 1911 Earthquakes

\begin{tabular}{ccccc}
\hline $\begin{array}{c}\text { Date } \\
\text { (year-month-day) }\end{array}$ & Time & Latitude & Longitude & Location \\
\hline $1911-03-21$ & $14: 15: 35.0$ & $38.017^{\circ} \mathrm{N}$ & $1.217^{\circ} \mathrm{W}$ & Cotillas \\
$1911-04-03$ & $11: 11: 11.0$ & $38.100^{\circ} \mathrm{N}$ & $1.200^{\circ} \mathrm{W}$ & Lorquí \\
\hline
\end{tabular}

Table 2

Times, Hypocenters, and Magnitudes for the Mula and Bullas Series

\begin{tabular}{ccccccc}
\hline $\begin{array}{c}\text { Date } \\
\text { (ddmmyy) }\end{array}$ & Ref & $\begin{array}{c}\text { Time } \\
\text { (UCT) }\end{array}$ & $\begin{array}{c}\text { Latitude } \\
{ }^{\circ} \mathrm{N}\end{array}$ & $\begin{array}{c}\text { Longitude } \\
{ }^{\circ} \mathrm{W}\end{array}$ & $\begin{array}{c}\text { Depth } \\
m_{\mathrm{b}}\end{array}$ \\
\hline 020299 & MF & $13: 22: 50.69$ & 38.05 & 1.47 & 7 & 4.3 \\
020299 & MM & $13: 45: 17.67$ & 38.10 & 1.50 & 1 & 5.5 \\
020299 & M1 & $17: 13: 17.79$ & 38.08 & 1.51 & 3 & 4.1 \\
030299 & M2 & $02: 02: 29.69$ & 38.06 & 1.52 & 3 & 4.3 \\
060802 & BM & $06: 16: 19.00$ & 37.88 & 1.83 & 1 & 5.5 \\
$060802 *$ & BM & $06: 16: 18: 59$ & 37.91 & 1.84 & 5 & - \\
060802 & B1 & $11: 55: 16.56$ & 37.89 & 1.82 & 11 & 4.9 \\
$060802 *$ & B1 & $11: 55: 15.07$ & 37.91 & 1.82 & 8 & - \\
060802 & B2 & $19: 25: 07.06$ & 37.90 & 1.83 & 11 & 4.0 \\
$060802 *$ & B2 & $19: 25: 05.98$ & 37.91 & 1.83 & 8 & - \\
070802 & B3 & $23: 09: 07.81$ & 37.86 & 1.84 & 1 & 4.4 \\
$070802 *$ & B3 & $23: 09: 06.77$ & 37.90 & 1.82 & 4 & - \\
\hline
\end{tabular}

*This study.

5.5 ) as the Bullas main shock (BM, $m_{\mathrm{b}} 5.5$; Table 2). In order to compare the 1911 events with the Mula and Bullas shocks, we estimated the surface-wave magnitude $M_{\mathrm{s}}$ using the IASPEI formula for the MM and BM events. A value of $5.3 \pm 0.3$ has been found for MM using five stations with epicentral distances between 197 and $595 \mathrm{~km}$. For BM, the magnitude obtained from 17 records (for stations at epicentral distances from $109-750 \mathrm{~km}$ ) is $5.2 \pm 0.2$. From these results, we conclude that the March 1911 earthquake had the largest shock $\left(M_{\mathrm{s}} 5.7\right)$, the April 1911 and the Mula main shock have the same magnitude $\left(M_{\mathrm{s}} 5.3\right)$, and the Bullas main shock has the lowest magnitude $\left(M_{\mathrm{s}} 5.2\right)$. These results are consistent with the damage caused by these earthquakes and the intensity values obtained for this article.

\section{Focal Mechanisms}

We determined focal mechanisms for the Mula and Bullas earthquakes from the first motion of $P$ waves, using the algorithm of Brillinger et al. (1980) (Fig. 6; Table 3). Takeoff angles have been estimated using a crustal model with a linear gradient of velocity over a mantle with different gradient (Buforn et al., 1988). For the Mula series, fault plane solutions were obtained in a previous paper by Buforn and Sanz de Galdeano (2001). We have used the new hypocentral coordinates (IGN; Table 2) to estimate a new solution, adding one polarity data point for the main shock. Solutions obtained for the Mula series (Fig. 6) correspond to thrust motion, with a vertical plane trending east-west, and dipping to the north for the main shock (MM) and the first aftershock (M1); for the second aftershock (M2), this vertical plane trends north-northeast-south-southwest. The solution obtained for the foreshock (FM) is also of thrust motion, but with the planes dipping $45^{\circ}$ in the northwest-southeast direction. We have obtained horizontal pressure axes for the four earthquakes, trending north-south to north-northeastsouth-southwest, except for the M2 event, which has a northwest-southeast trend. For the Bullas series, solutions obtained (Fig. 6) for events BM, B1, and B3 correspond to strike-slip motion with vertical planes oriented north-south and east-west. Horizontal pressure and tension axes trend northwest-southeast and northeast-southwest, respectively. Normal faulting with planes dipping about $45^{\circ}$ and oriented in the northwest-southeast direction has been found for event M2.

The main shock of the Mula sequence (MM) has a wellconstrained solution, with 28 polarity data and errors for the $T$ and $P$ axes less than $15^{\circ}$ (Table 3 ). The MF and M1 earthquakes have poorly constrained solutions, with errors larger than $15^{\circ}$, because of the few observations ( 8 and 9 , respectively). The solutions for the Bullas sequence, in general, are well constrained, especially for the main shock (37 observations), with low errors for the $T$ and $P$ axes; only the B2 event has errors larger than $15^{\circ}$ because of the few observations (10).

We have estimated scalar seismic moment $\left(M_{\mathrm{o}}\right)$ from spectral analysis of $P$ waves and, assuming a circular fracture model, focal dimensions of 2r (Brune, 1970) (Table 3). This hypothesis is valid for small to moderate shocks ( $m$ 6.0). For the Mula series, we estimated the scalar seismic moment only for the main shock (MM), owing to the low magnitude of the sequence. For the Bullas series, with the broadband stations, we were able to obtain better estimations of $M_{\mathrm{o}}$ and the focal dimensions for the main shock and the three larger aftershocks. For the Mula main shock, we used eight spectra to obtain $M_{\mathrm{o}} 5.9 \times 10^{16} \mathrm{~N} \mathrm{~m}$, which corresponds to $M_{\mathrm{w}} 5.1$. We estimated the focal dimensions as $2 \mathrm{r}=4.0 \mathrm{~km}$ (Table 3). For the Bullas series, we used 12, 6,3 , and 6 spectra, respectively, obtaining $M_{\mathrm{o}}=8.7 \times 10^{15}$ $\mathrm{N} \mathrm{m}$ for the main shock and values down to $1.3 \times 10^{13} \mathrm{~N} \mathrm{~m}$ for aftershock B2; these values correspond to magnitudes $M_{\mathrm{w}}$ between 2.7 and 4.6 (Table 3). Dimensions obtained for the Bullas series are from $1.5 \mathrm{~km}$ for the main shock to $0.6 \mathrm{~km}$ for the smallest aftershock (B2).

We obtained source time functions (STF) for the Mula and Bullas main shocks, using aftershocks M1 and B3, respectively, as empirical Green functions (EGF, Fig. 7; Mori and Frankel, 1990). Focal mechanisms for the main shocks and these aftershocks are similar, and the difference in magnitudes is sufficient for us to apply this methodology (Fig. 6). For the Mula earthquake, we were only able to use the CART station (epicentral distance $72 \mathrm{~km}$, azimuth $144^{\circ}$ ), but we were able to use $P$ and $S$ waves recorded on the three components and channel HH (100 samples/sec). For the Bullas earthquake, we used three components of $P$ waves re- 


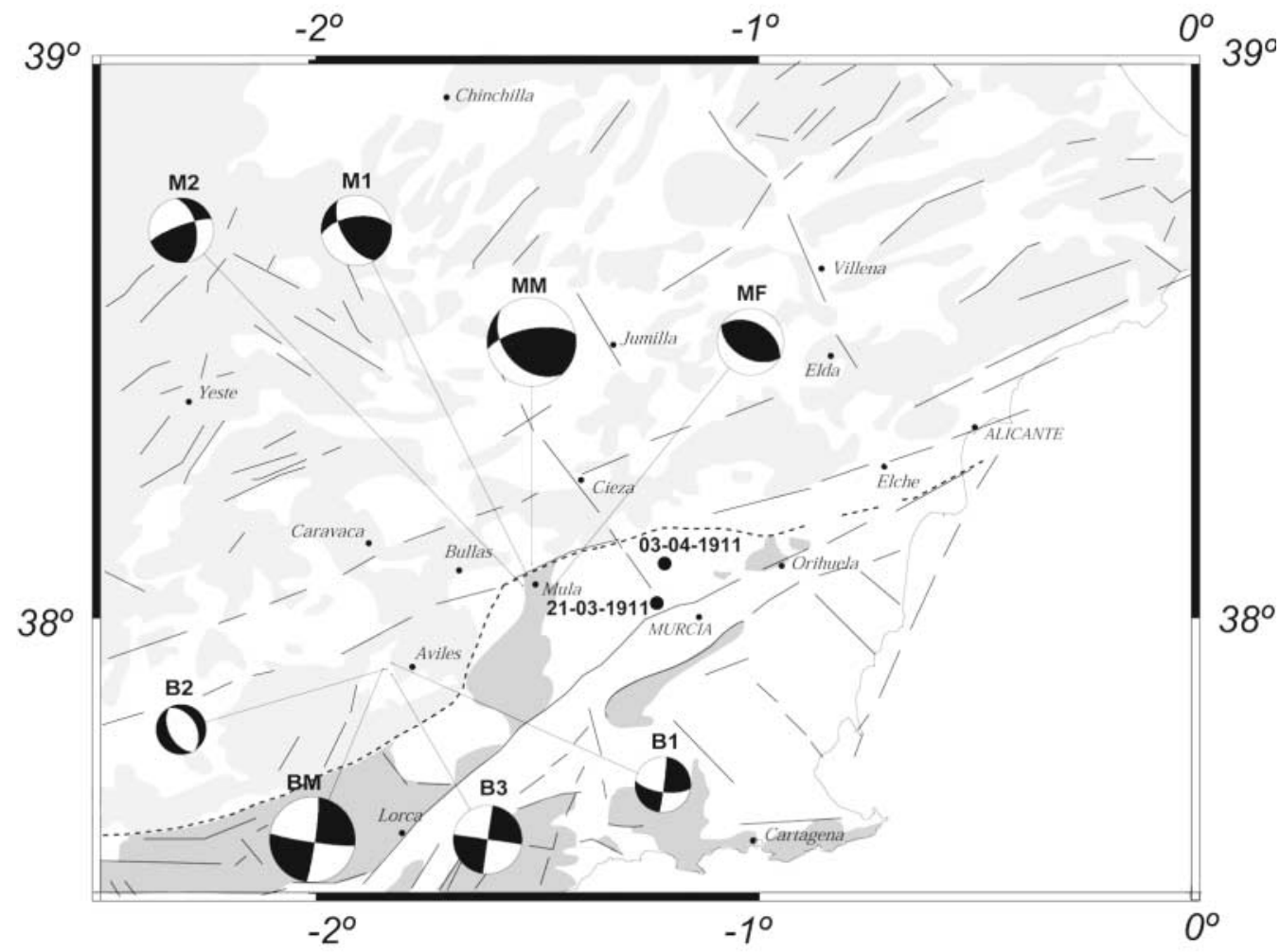

Figure 6. Focal mechanisms for the Mula and Bullas earthquake sequences, together with the main geological features for the studied region (same region as shown in [b] in Fig. 1). Size is proportional to magnitude. Macroseismic epicenters for the 1911, black circles.

Table 3

Focal Mechanisms and Seismic Moments of the Mula and Bullas Earthquakes

\begin{tabular}{|c|c|c|c|c|c|c|c|c|c|}
\hline \multirow[b]{2}{*}{ Event } & \multicolumn{2}{|c|}{$T$ axis } & \multicolumn{2}{|c|}{$P$ axis } & \multirow[b]{2}{*}{$\mathrm{N}$} & \multirow[b]{2}{*}{ Score } & \multirow[b]{2}{*}{$M_{\mathrm{o}}(\mathrm{N} \mathrm{m})$} & \multirow[b]{2}{*}{$2 \mathrm{r}(\mathrm{km})$} & \multirow[b]{2}{*}{$M_{\mathrm{w}}$} \\
\hline & $\Theta$ & $\Phi$ & $\Theta$ & $\Phi$ & & & & & \\
\hline MF & $87 \pm 24$ & $29 \pm 55$ & $3 \pm 23$ & $209 \pm 61$ & 8 & 1.00 & & & \\
\hline MM & $57 \pm 6$ & $127 \pm 7$ & $15 \pm 6$ & $12 \pm 10$ & 28 & 0.93 & $5.9 \times 10^{16}$ & 4.0 & 5.1 \\
\hline M1 & $48 \pm 24$ & $116 \pm 16$ & $1 \pm 8$ & $26 \pm 18$ & 9 & 0.89 & & & \\
\hline M2 & $53 \pm 40$ & $202 \pm 27$ & $77 \pm 15$ & $305 \pm 27$ & 15 & 0.80 & & & \\
\hline $\mathrm{BM}$ & $1 \pm 7$ & $53 \pm 2$ & $7 \pm 14$ & $323 \pm 1$ & 37 & 1.00 & $8.7 \times 10^{15}$ & 1.5 & 4.6 \\
\hline B1 & $13 \pm 7$ & $54 \pm 6$ & $18 \pm 7$ & $320 \pm 4$ & 25 & 0.88 & $3.5 \times 10^{13}$ & 0.6 & 3.0 \\
\hline B2 & $5 \pm 24$ & $241 \pm 82$ & $85 \pm 23$ & $91 \pm 66$ & 10 & 1.00 & $1.3 \times 10^{13}$ & 0.8 & 2.7 \\
\hline B3 & $1 \pm 20$ & $233 \pm 1$ & $1 \pm 47$ & $143 \pm 1$ & 17 & 1.00 & $4.2 \times 10^{14}$ & 1.1 & 3.7 \\
\hline
\end{tabular}

$\Theta=$ plunge.

$\Phi=$ trend.

corded at EMUR (epicentral distance $53 \mathrm{~km}$, azimuth $98^{\circ}$ ) and ETOB (epicentral distance $83 \mathrm{~km}$, azimuth $19^{\circ}$ ). STF are shown in Figure 7. A triangular pulse was obtained for both shocks, with similar duration $(<0.1 \mathrm{sec})$.

The main difference between the Mula and Bullas earthquake series is their focal mechanisms (Figs. 6 and 8). For the Mula series, focal mechanisms are thrust, while for the Bullas series, focal mechanisms are strike-slip, with the exception of the second aftershock (B2), which is normal. A vertical plane striking in an east-west direction has been obtained for the larger events (MM, BM, B3); subhorizontal pressure axes trending in a north-south direction for the Mula series and in a northwest-southeast direction for the Bullas series also were found.

The focal mechanism of the Mula main shock has been studied by Mancilla et al. (2002) and Stich et al. (2003) using moment tensor inversion of waveforms of surface waves from seven stations located at regional distances. The INGV RCMT catalog (http://www.ingv.it/seismoglo/ RCMT, last accessed, December 2003) shows a solution for the MM obtained from surface wave inversion (six stations at regional and teleseismic distances). Obviously, a solution 


\section{Mula mainshock (2 February 1999) Bullas mainshock (6 August 2002)}

\section{Station: CART}
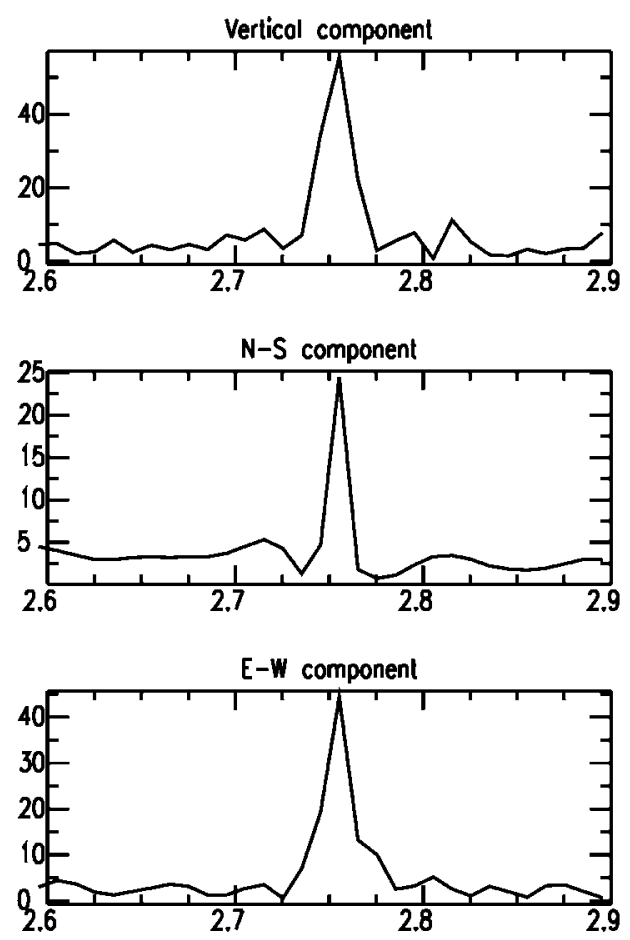

Station: ETOB
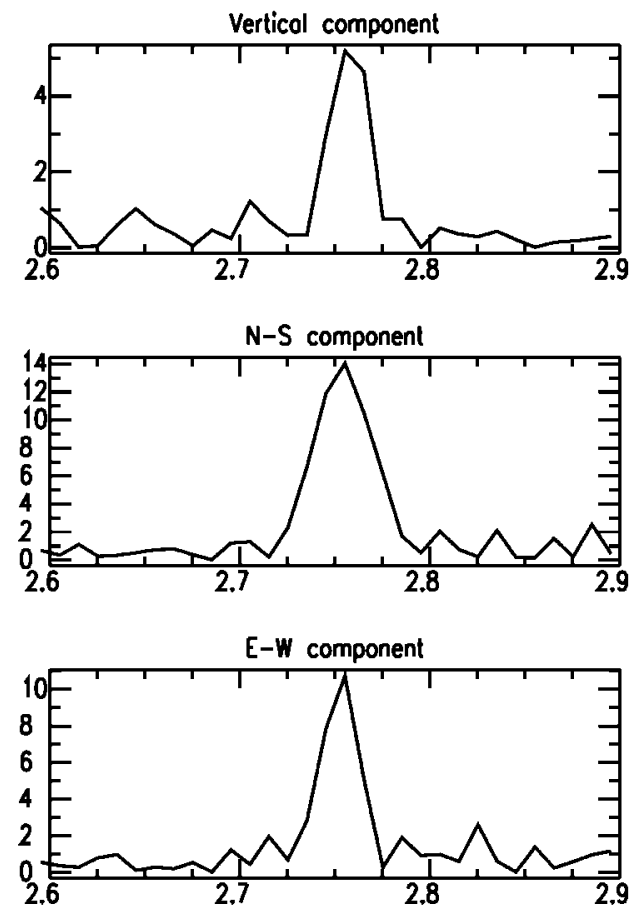

Figure 7. Source time functions (STF) obtained by deconvolution between main shock (MM) and aftershock (M1) for Mula, and the main shock (BM) and aftershock (B2) for Bullas. Horizontal scale, seconds; vertical scale, $M_{\mathrm{o}}$ of the EGF.

obtained from waveform inversion is more robust than solutions obtained from polarities when a large number of data are used. However, the moment tensor inversion from surface waves requires detailed knowledge of group and phase velocity along the path from the epicenters to stations. Iberia is a very complex region, with important lateral heterogenieties, and the use of only three 1D models may introduce some ambiguities on the solution. In Figure 9, solutions obtained for MM by different authors with the polarities used in our solution are shown. Results obtained by Mancilla et al. (2002) and Stich et al. (2003) are very similar; both show strike-slip faulting with a normal component, and with one plane striking $50^{\circ} \mathrm{N}$, with dip $70^{\circ}$ and rake $-30^{\circ}$ (Mancilla et al., 2002) and striking $41^{\circ} \mathrm{N}$, with dip $69^{\circ}$ and rake $26^{\circ}$ (Stich et al., 2003). The ING RCMT solution is very close to our solution, striking $22^{\circ} \mathrm{N}$, with dip $49^{\circ}$ and slip $41^{\circ}$, and agrees with the character of a reverse fault. From consideration of the polarity data, both solutions (strike-slip with normal component and reverse faulting) are equally in agree- ment with the observations. However, we prefer our solution-reverse faulting-due to agreement with the focal mechanisms of the foreshock and aftershocks, all with reverse motion. Also, the strike obtained in our solution for one plane is approximately $80^{\circ} \mathrm{N}$, similar to the trend of Cadiz-Alicante fault in this area. However, the four solutions plotted in Figure 9 have a common feature: a similar orientation for the pressure axis. It almost horizontal and trends north-south in Mancilla et al. (2002), Stich et al. (2003), and our study, and northwest-southeast in the ING solution. Another point of disagreement is the depth obtained by these authors. Mancilla et al. (2002) obtained 7.5-12.5 km, Stich et al. (2003) $8 \mathrm{~km}$, and ING RTCN $27 \mathrm{~km}$. These values are greater than the depth obtained by the IGN $(1 \mathrm{~km})$, and are very well constrained, with $105 P$ - and $S$-arrival times and an azimuthal gap of only $42^{\circ}$. This type of data can effectively discriminate between $1-2 \mathrm{~km}$ and $7-12 \mathrm{~km}$. A very shallow earthquake seems to be more in agreement with the damage caused by this earthquake (Tordesillas et al., 2003). 

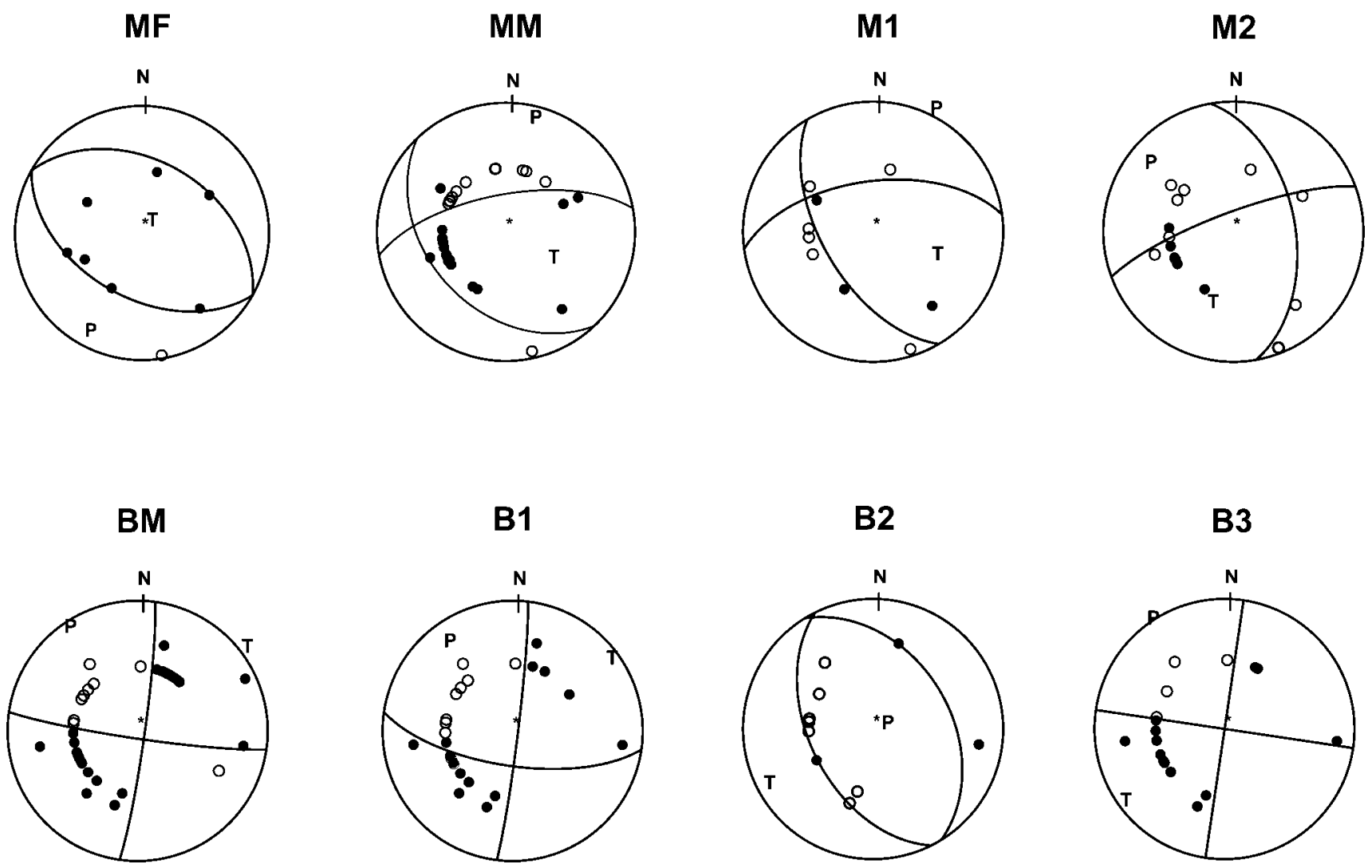

Figure 8. Fault plane solutions for the Mula and Bullas sequences. Stereographic projections of lower hemisphere are represented. Compressions, black circles; dilatations, white circles; pressure axis, $\mathrm{P}$; tension axis, $\mathrm{T}$.

The scalar seismic moment obtained by different authors is similar: Mancilla et al. (2002), $1.3 \times 10^{16} \mathrm{~N} \mathrm{~m}$; Stich et al. (2003), $1.7 \times 10^{16} \mathrm{~N} \mathrm{~m}$; ING, $1.5 \times 10^{16} \mathrm{~N} \mathrm{~m}$; and our value, $5.6 \times 10^{16} \mathrm{~N} \mathrm{~m}$.

\section{Strong Ground Motion}

The Mula and Bullas main shocks were recorded by 6 and 11 accelerographs, respectively, of IGN at epicentral distances between 21 and $340 \mathrm{~km}$ (Table 4). These are the first Spanish earthquakes to produce a large number of strong motion records. The nearest station for the Mula main shock is Lorquí (LOQ; epicentral distance, 21 km; Fig. 10), where the PGA on the two horizontal components was $0.012 \mathrm{~g}$, (Fig. 11a; Table 4); PGAs from 0.001-0.005 g were recorded at the other stations. The maximum PGA for the Bullas main shock was $0.020 \mathrm{~g}$ on the east-west component, recorded at the Mula station (MUL) at a distance of $32 \mathrm{~km}$ (Fig. 11b; Table 4). At the nearest station, Lorca (LOR; $28 \mathrm{~km}$ ), the PGA was lower (0.007 g). These differences may be explained by site effects. Because no velocity profiles exist for this area, we were unable to estimate the transfer functions and amplification factors. However, the ground at both sites may explain differences in their behavior. The Lorquí station is on limestone, while Mula is on Quaternary alluvium. At the other stations, PGA values for the Mula and Bullas shocks were between $0.013 \mathrm{~g}$ and $0.001 \mathrm{~g}$. For both earthquakes, the recorded motion was quite low, with peak values less than $0.02 \mathrm{~g}$. These low values are explained by the lack of stations in the epicentral region.

The acceleration response spectra for $5 \%$ critical damping in Lorquí (for the Mula earthquake) and in Mula (for the Bullas earthquake) stations are shown in Figures 11a and 11b. The spectral accelerations are lower than $0.1 \mathrm{~g}$ in both cases, with the maximum of response spectra centered at about $10 \mathrm{~Hz}$ for the Mula shock, and at about $8 \mathrm{~Hz}$ for the Bullas earthquake.

We have used European strong motion models of Tento et al. (1992) Ambraseys et al. (1996), and Sabetta and Pugliese (1996) to estimate response spectra in the epicentral area. For an $M_{\mathrm{w}} 4.8$ earthquake (average of $M_{\mathrm{w}}$ estimated for Mula and Bullas main events) at an epicentral distance of $8 \mathrm{~km}$ for rock site conditions, the PGA ranges, according to these models, is between 0.10 and $0.15 \mathrm{~g}$, which corresponds to an intensity range VI-VII. Results obtained for the different models are shown in Figure 12. This modeling gives a maximum acceleration response of $0.7 \mathrm{~g}$ at a frequency of $8 \mathrm{~Hz}$ with the Tento et al. (1992) model (the most conservative). Nevertheless, the spectral shapes using the different models are quite similar, and the main variations 
This study

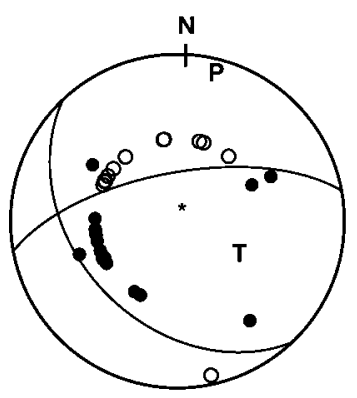

Stich et al. (2003)

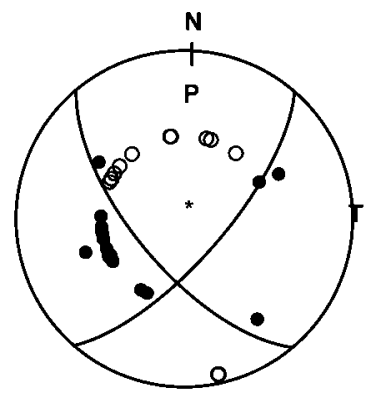

Mancilla et al. (2002)

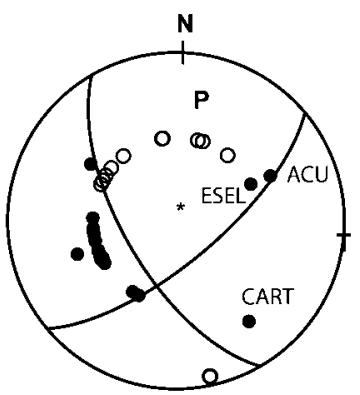

ING

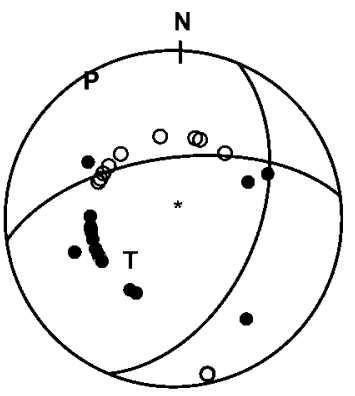

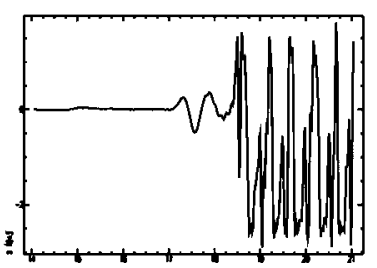
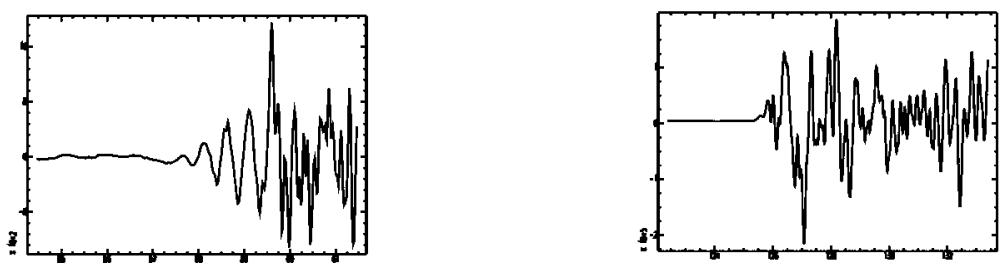

Figure 9. Focal mechanisms for Mula main shock obtained by different authors, black and white circles correspond to polarity data used in this study. Symbols as in Figure 6. Velocity records for vertical component for ACU, ESEL, and CART stations are shown at bottom.

Table 4

Ground Motions for the Mula and Bullas Earthquakes

\begin{tabular}{|c|c|c|c|c|c|c|c|c|}
\hline \multirow[b]{2}{*}{ Event } & \multirow[b]{2}{*}{ Station } & \multirow[b]{2}{*}{ Code } & \multirow{2}{*}{$\begin{array}{l}\text { Delta } \\
(\mathrm{km})\end{array}$} & \multirow[b]{2}{*}{ Instrument } & \multirow[b]{2}{*}{ Soil } & \multicolumn{3}{|c|}{ Maximum acceleration } \\
\hline & & & & & & $\mathrm{N}-\mathrm{S}$ & $\mathrm{V}$ & $\overline{E-W}$ \\
\hline MM & Lorquí & LOQ & 21.0 & GSR-M & Alluvium & 0.012 & 0.007 & 0.012 \\
\hline MM & Jumilla & JUM & 43.3 & GSR-M & Limestone, marl & 0.005 & 0.004 & 0.004 \\
\hline MM & Orihuela & ORI & 47.5 & SSA-1 & Alluvial mudstone & 0.001 & 0.000 & 0.001 \\
\hline MM & Lorca & LOR & 51.4 & GSR-M & Limestone, marl, sand & 0.005 & 0.002 & 0.004 \\
\hline MM & Torrevieja & TOR & 71.5 & GSR-M & Silt, clay & 0.002 & 0.002 & 0.003 \\
\hline MM & Alcoy & ALC & 110.4 & SSA-2 & Calcareous marl & 0.002 & 0.002 & 0.003 \\
\hline BM & Lorquí & LOQ & 53.6 & GSR-M & Alluvium & 0.009 & 0.006 & 0.010 \\
\hline $\mathrm{BM}$ & Mula & MUL & 32.5 & GSR-M & Quaternary & 0.016 & 0.010 & 0.020 \\
\hline $\mathrm{BM}$ & Lorca & LOR & 27.8 & GSR-M & Limestone, marl, sand & 0.007 & 0.004 & 0.004 \\
\hline BM & Vera & VER & 73.7 & GSR-M & Colluvium, Alluvium & 0.003 & 0.002 & 0.003 \\
\hline $\mathrm{BM}$ & Murcia & MU2 & 62.9 & GSR-18 & Alluvium & 0.004 & 0.002 & 0.002 \\
\hline $\mathrm{BM}$ & Olulla del Río & OLU & 130.2 & GSR-M & Dolomite & 0.003 & 0.002 & 0.001 \\
\hline $\mathrm{BM}$ & Jaén & JAE & 172.9 & GSR-M & & 0.003 & 0.001 & 0.004 \\
\hline BM & Cacín & CAC & 206.8 & SSA-2 & Gypsum, marl & 0.000 & 0.000 & 0.001 \\
\hline $\mathrm{BM}$ & Dúrcal & DUR & 184.1 & SSA-2 & Conglomerate, sand & 0.001 & 0.000 & 0.001 \\
\hline BM & Carmona & CAR & 339.5 & SSA-2 & Calcoarenite & 0.001 & 0.001 & 0.001 \\
\hline $\mathrm{BM}$ & Guadix & GDX & 132.0 & SSA-2 & Alluvium & 0.001 & 0.001 & 0.002 \\
\hline
\end{tabular}

MM: Mula main shock.

BM: Bullas main shock.

Delta: epicentral distance. 


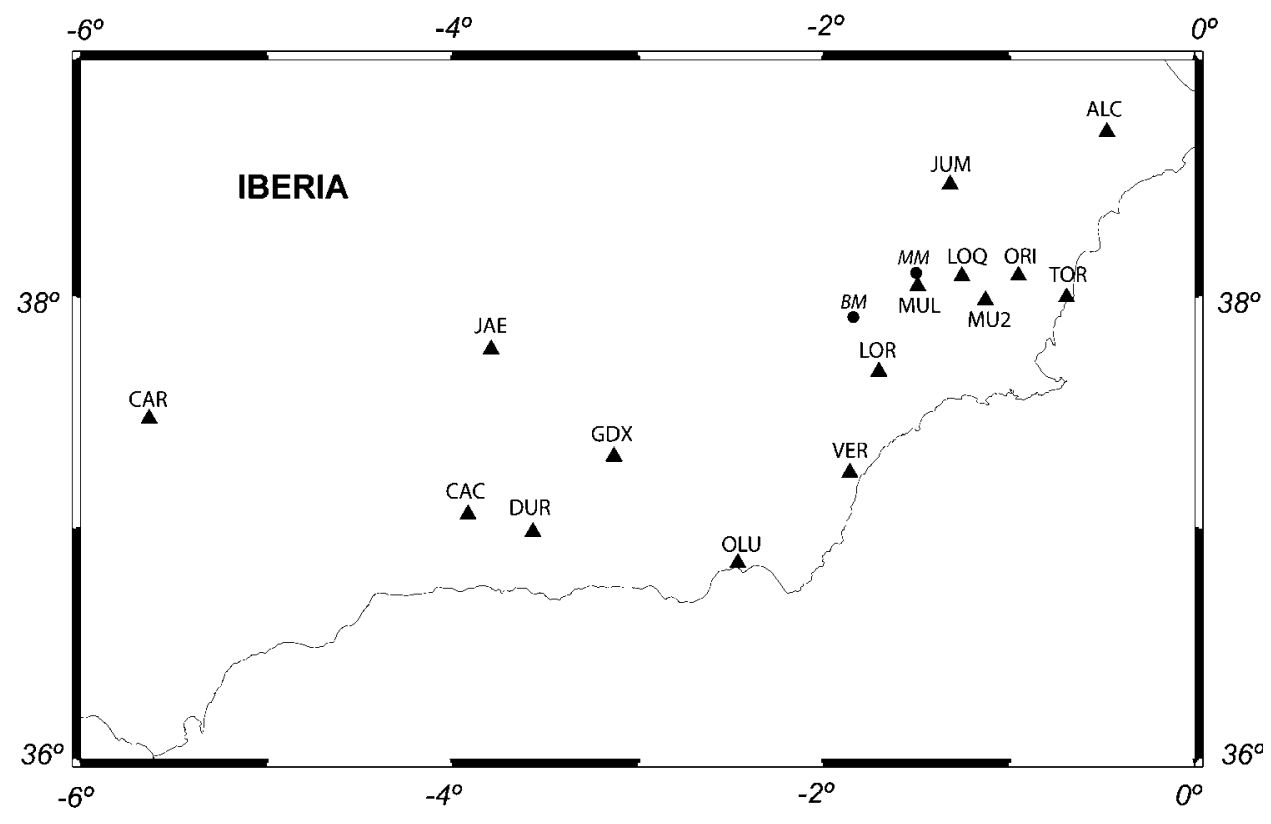

Figure 10. Location of strong motion stations for Mula and Bullas earthquakes, triangles; Mula and Bullas main shocks epicenters, circles.

in the spectral values are for frequencies greater than $2 \mathrm{~Hz}$. These results may be considered a preliminary approximation of the characteristic motion in the epicentral areas in the absence of real data. The models we used were obtained by a regression analysis that fitted recorded data to a law representing an average of spectral accelerations for each combination of magnitude, distance, and soil conditions. Therefore, the spectra obtained can be interpreted as the average predicted on rock sites for an earthquake of $M_{\mathrm{w}} 4.8$ at an epicentral distance of $8 \mathrm{~km}$.

The damage caused by the 1911 and Mula earthquakes was due to the shallow depth of these shocks, and to the accelerations reached in the epicentral area. From Table 2 we see that the Mula and Bullas series were at very shallow depths (less than $11 \mathrm{~km}$ ). These depths are confirmed by the intensity maps for both earthquakes since the largest intensities (VIII) are concentrated in a very small region around.

\section{Seismic Hazard}

Results obtained in this study have been used to obtain a more detailed seismic hazard map for Murcia region. This region is a zone with moderate seismic hazard, where there have been several damaging earthquakes in the twentieth century. In the hazard map of the Spanish Building Code NCSE-2002 (SBC Map, Figure 13a), the Murcia region has assigned acceleration values between 0.04 and $0.16 \mathrm{~g}$, corresponding to exceedence probabilities of $10 \%$ in 50 years. Most of the region is in the PGA interval 0.08-0.12 g, while the eastern and southern areas have a higher hazard, with a PGA range of $0.12-0.16 \mathrm{~g}$. It is important to note that the
Spanish Building Code map, based on general assumptions, was developed for the whole country.

In order to approximate the seismic hazard for the Murcia region, we have made a new study of intensity from the available historical seismicity data, because of the long recurrence intervals between the large earthquakes and the lack of sufficient instrumental data. We have used the IGN catalogue, updated to 2002, and taken as a starting point the seismogenetic zones of the SBC map.

We implemented the probabilistic approach of Cornell (1969) with the EQRISK program (McGuire, 1976). Before the application of this program, we analyzed the completeness of the catalogue; the parameters of the different zones considered were estimated (i.e., maximum intensity and the parameters $a$ and $b$ of the Gutenberg-Richter law $[\log \mathrm{N}=$ $a-b M])$. The minimum intensity was fixed at IV for all the zones. This study gives the intensity values for a return period of 475 years — equivalent to $10 \%$ for 50 years-for a network of points covering the Murcia region.

From these values, the peak accelerations have been obtained by application of the intensity-acceleration relationship proposed by Margottini et al. (1989) from European data. This law was developed from strong motion data recorded under the same conditions (geological and geomorphological) as the macroseismic data. Hence we expect that the local conditions have the same influence on the PGA values as on the intensities, reducing the uncertainty of the relationship. This has been our main criterion for choosing this law, as well as the fact that the tectonic regime of the original data was similar to that of the Iberian Peninsula.

The hazard map is shown in Figure 13b. The expected PGA values in the Murcia region, for a return period of 475 


\section{Earthquake: Mula, 2 February, 1999}

\section{Accelerograms}

(a)
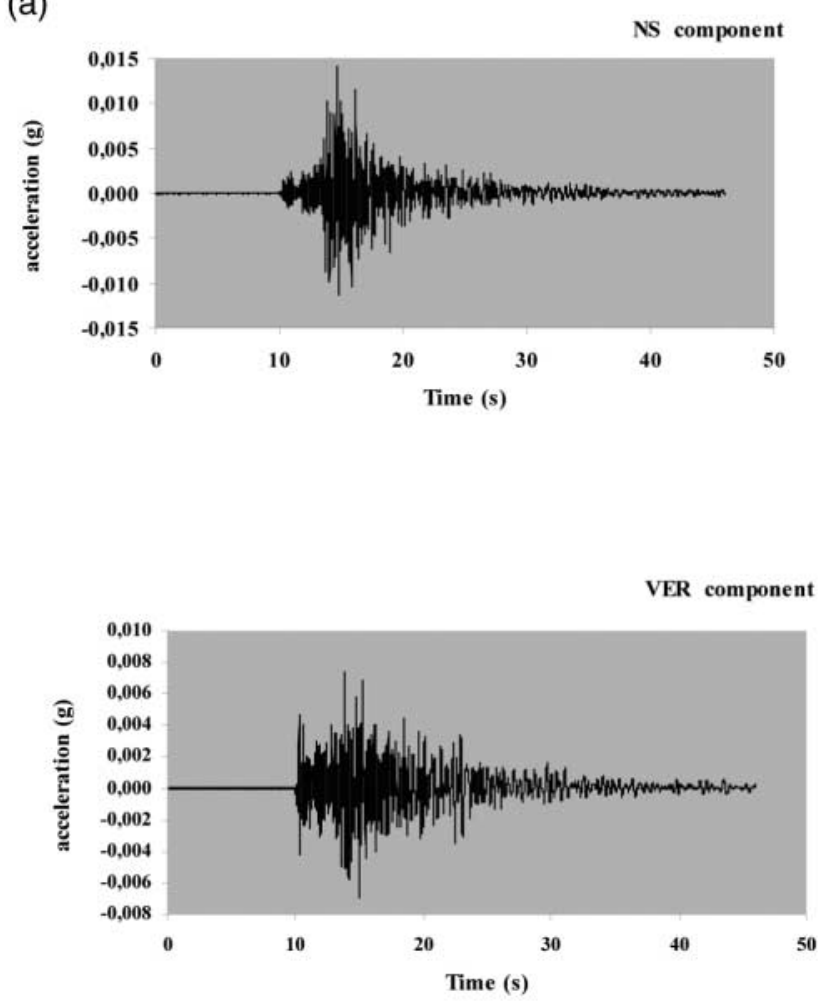

EW component

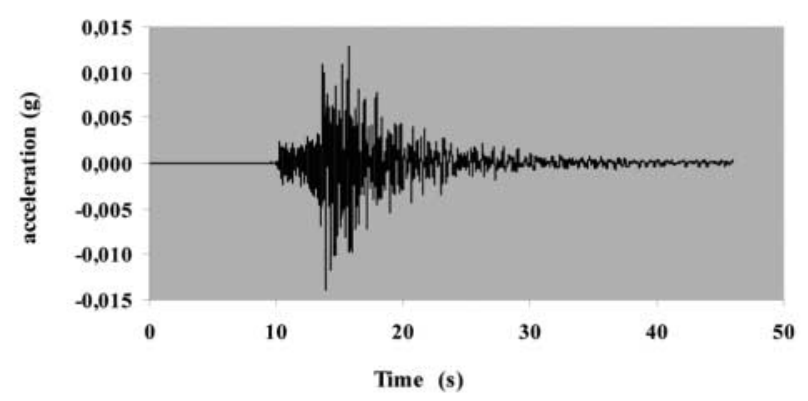

Station: Lorquí

\section{Acceleration Response spectra}
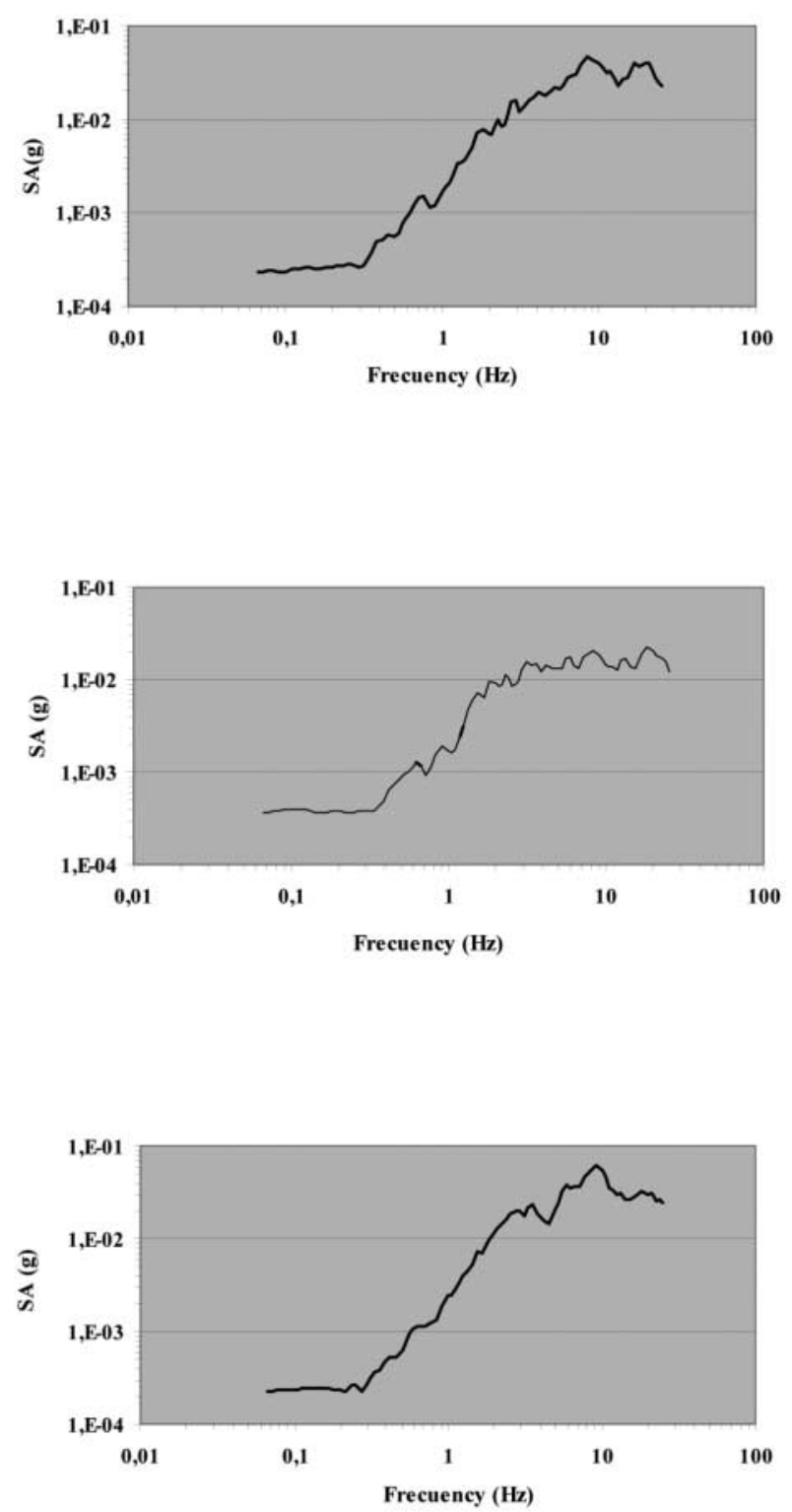

Figure 11. Strong motion records and acceleration response spectra for Mula and Bullas main shock. (a) for Mula earthquake, three components of the Lorquí station (at left) together with the acceleration response spectra for a 5\% critical damping (right) are shown.

(continued)

years, are between $0.08 \mathrm{~g}$ in Cartagena and $0.24 \mathrm{~g}$ in the eastern area, near Murcia city, and in the southeastern region, near Almería. The hazard in the north is lower, with PGA around $0.14 \mathrm{~g}$. The expected value in Mula is $0.16 \mathrm{~g}$, in agreement with our PGA value empirically estimated in the epicentral area. This agreement could be interpreted to mean the motion produced by the Mula earthquake is exactly that associated with the $10 \%$ excedeence probability in 50 years. For locations such as Campos del Río and Albudeite, higher values, between 0.18 and $0.20 \mathrm{~g}$, have been obtained. 
Earthquake: Bullas, 6 August, 2002

\section{Accelerograms}

(b)
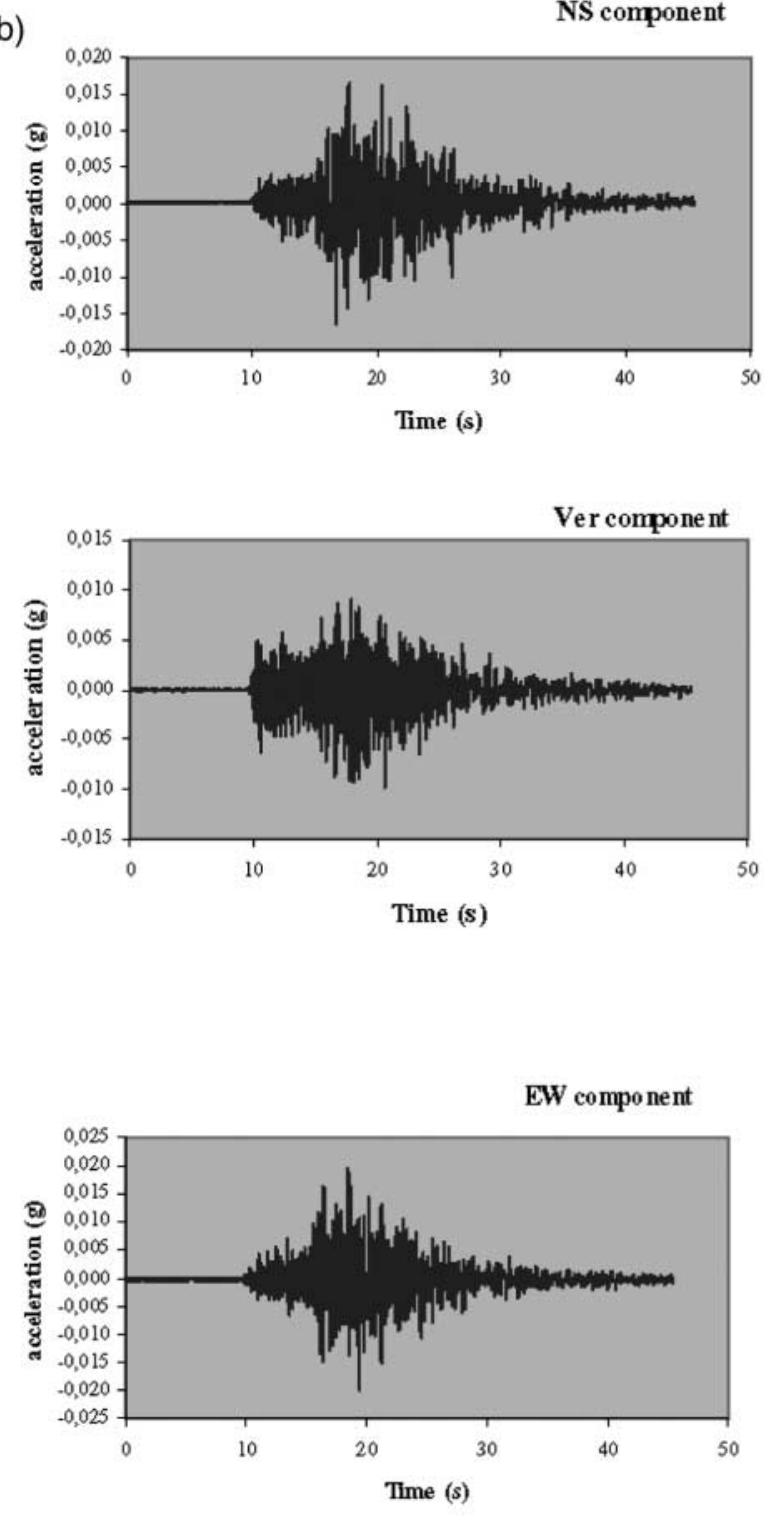

\section{Station: Mula}

Acceleration Response spectra
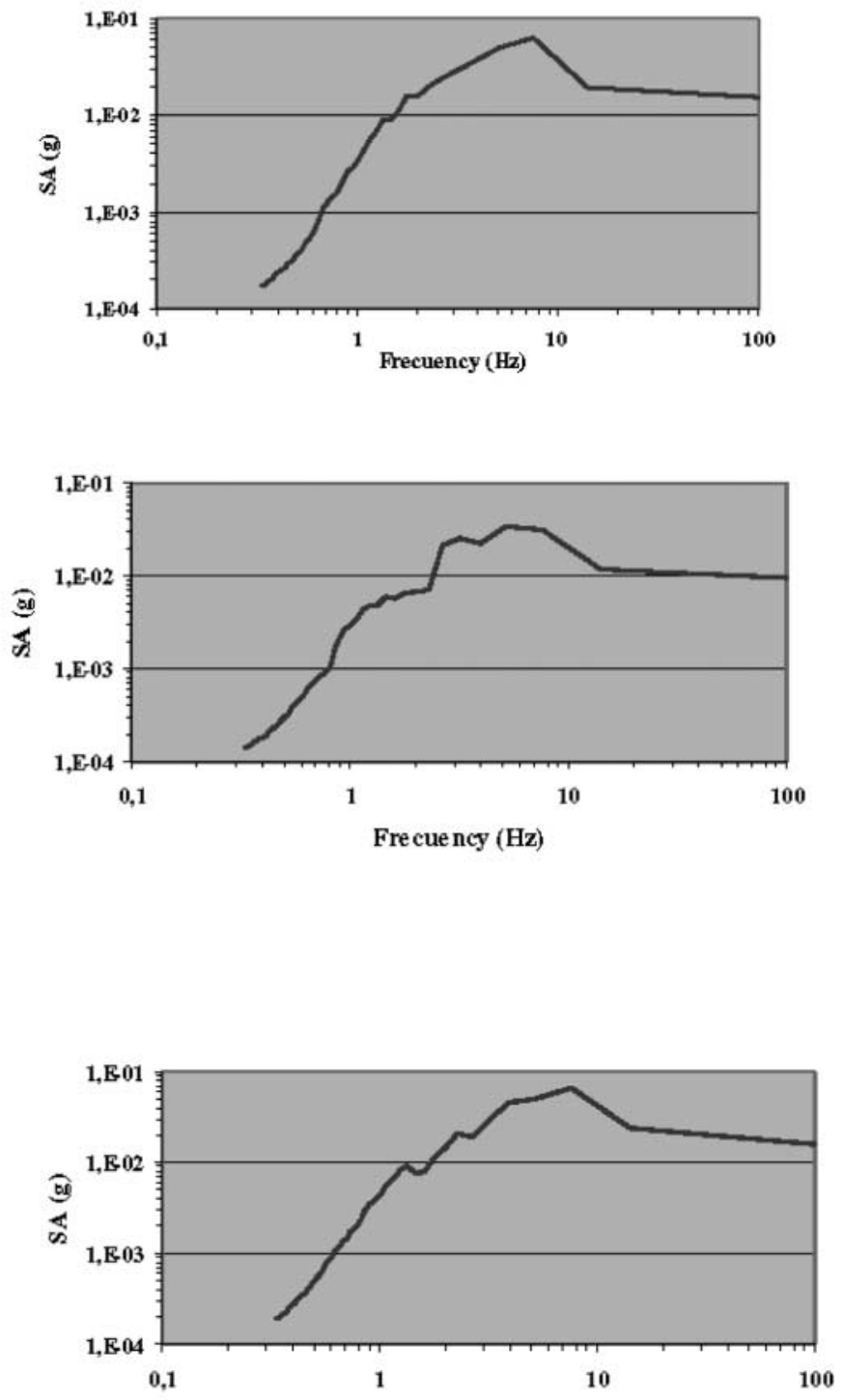

Frecuency $(\mathrm{Hz})$

Figure 11. Continued. (b) for the Bullas shock, records and spectra correspond to the Mula station.

Consequently, stronger ground motion than that associated with the 1999 earthquake is expected in this area.

For other sites where accelerographs were triggered by the Mula and Bullas earthquakes, the recorded values of PGA were notably lower than those given in the Figure 12. This is the case for Jumilla, Lorca, Lorquí, and Murcia, where the hazard assessment gives values of $0.14 \mathrm{~g}, 0.21 \mathrm{~g}, 0.22 \mathrm{~g}$, and $0.24 \mathrm{~g}$, respectively, while the recorded PGA in both earthquakes were lower than $0.020 \mathrm{~g}$. The hazard in these places does not appear to be dominated by earthquakes such as those of 1999 near Mula, and of 2002 near Bullas, since stronger motions are expected in other parts of the region. 


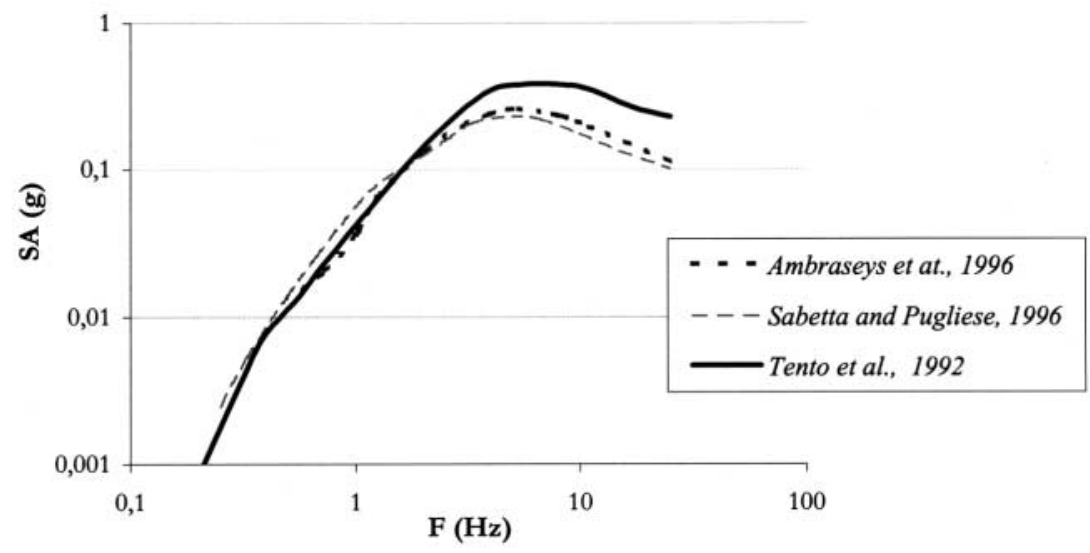

Figure 12. Response spectra estimated for a $M_{\mathrm{w}} 4.8$ earthquake at an epicentral distance of $8 \mathrm{~km}$ for rock site conditions using different strong motion models.

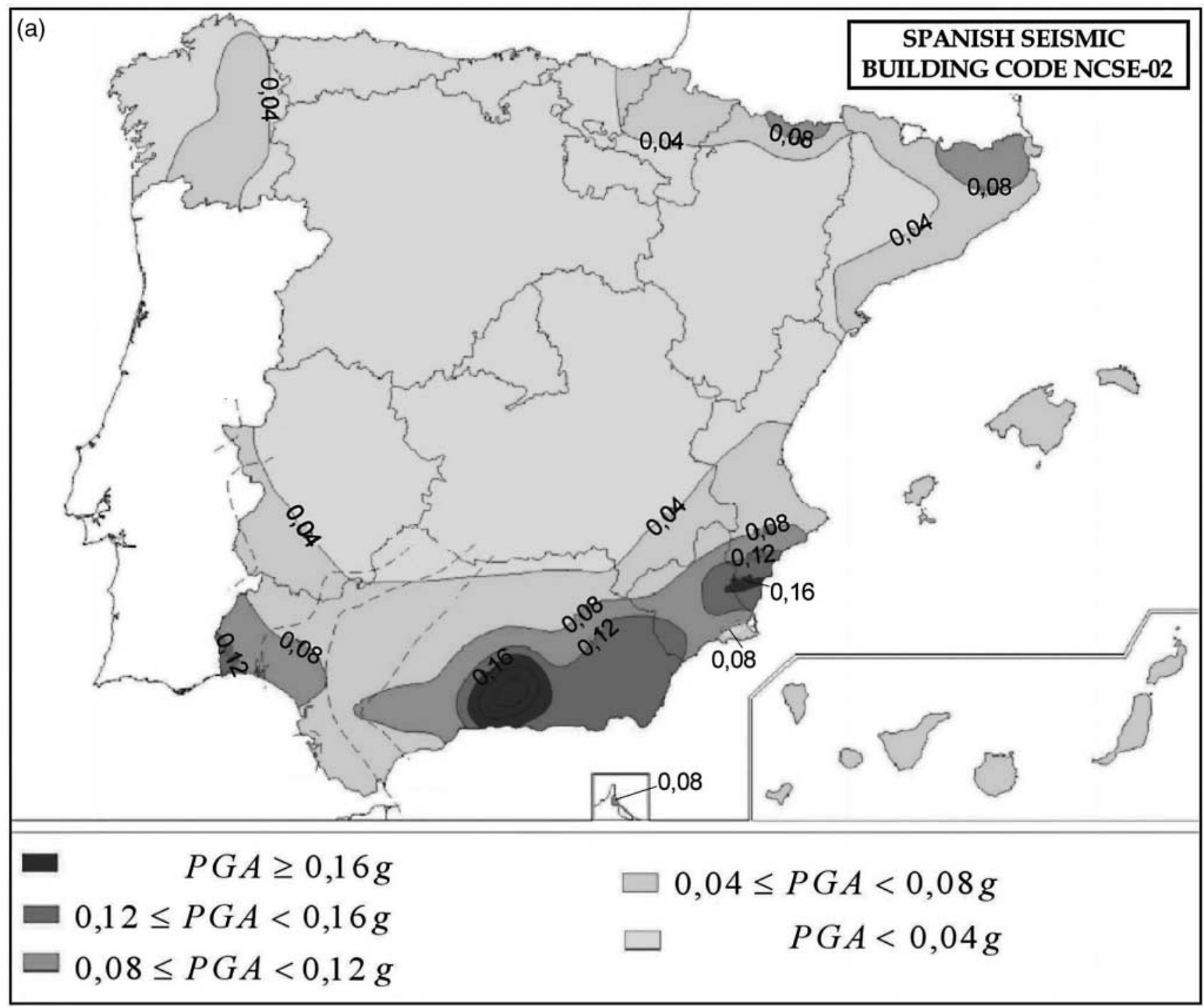

Figure 13. (a) Seismic hazard map of NSCE-02; (b) the map obtained in this study for the Murcia region for a return period of 475 years. PGA values are given in terms of $\mathrm{g}$.

(continued) 


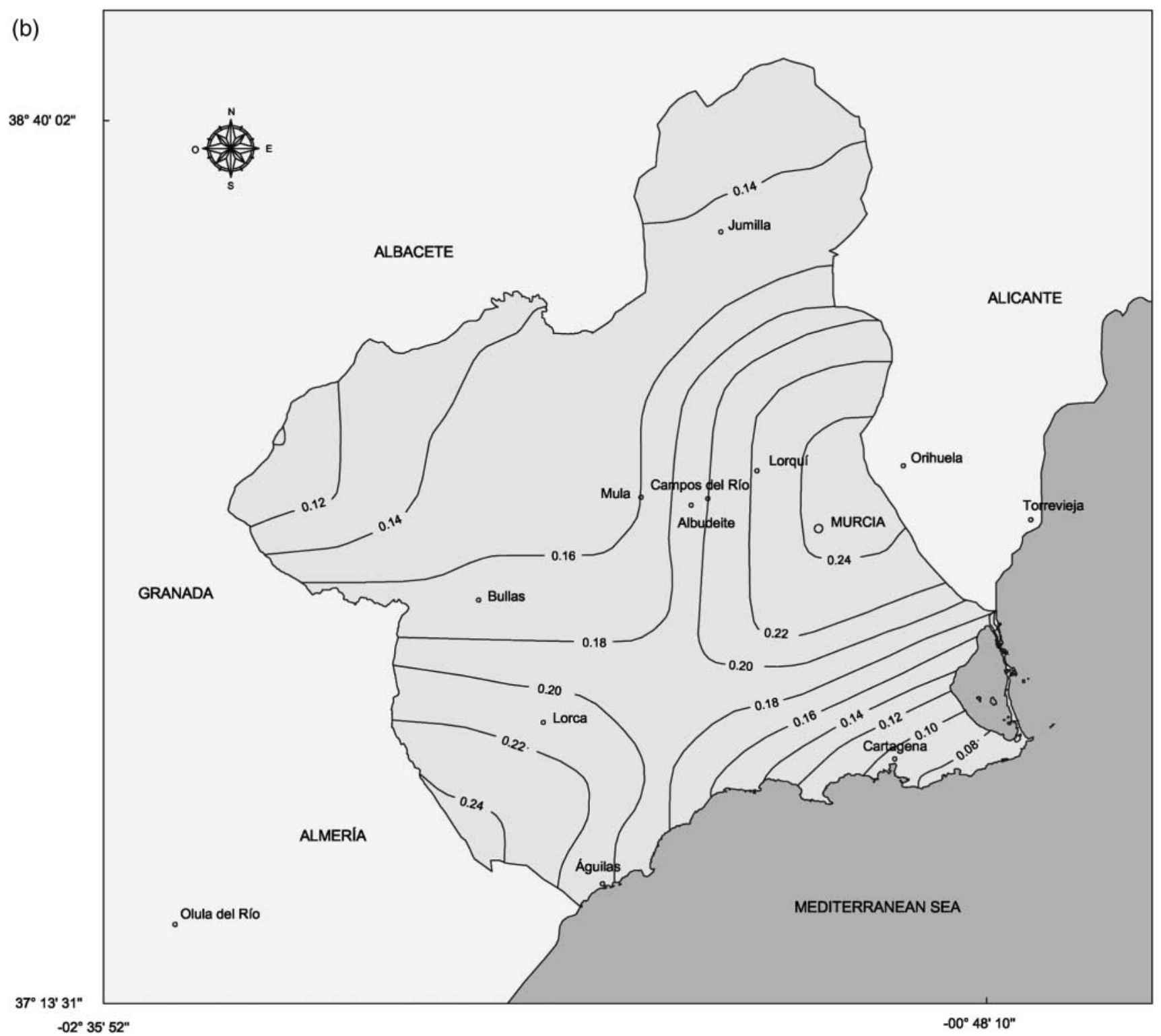

Figure 13. Continued.

This agrees with the occurrence of the 1911 earthquakes with larger intensities and magnitudes than the Mula and Bullas earthquakes.

From the comparison between our results and the SBC map (NCSE-02), we see that the map obtained in this study is more conservative than the one of the NCSE-02. The morphology is not very different in both maps, with quite similar shapes of the isolines of PGA, although we have more detail in the intervals between them due to the scale of the work. However, the PGA values obtained here are higher than those of the SBC map. The difference between the maps depends on the zone inside the region, and is larger in those parts with higher hazard. For example, in the city of Murcia, located in the eastern part of the region, the PGA has a value of $0.15 \mathrm{~g}$ on the NCSE-02 map and $0.24 \mathrm{~g}$ in our study. In
Lorca, the PGA has a value of $0.12 \mathrm{~g}$ in the NCSE-02 map and $0.21 \mathrm{~g}$ in Figure 10. In zones with a lower hazard, the differences between both maps are lower. Cartagena, for instance, has a value of $0.07 \mathrm{~g}$ in the building code and $0.10 \mathrm{~g}$ on our map.

These differences can be explained mainly by the relation used in the conversion from intensity to acceleration. In the case of the SBC map, the relation has been adapted from Medvedev and Sponheuer (1969), which is one of the less conservative among all of those proposed by authors in our references. However, in our map the relation of Margottini et al. (1989) that we have adopted lies in the central band of the different relations proposed. The large dispersion in the intensity-acceleration relations is an important source of uncertainty in our results, since very different values of ac- 
celeration can be associated with the same intensity, as it is well known. Therefore, this is a critical point in our study; but in our opinion, the law we have adopted is more realistic and conservative than the ones employed in the Spanish building code. The original data considered in the relationship of Margottini et al. (1989) seem more suitable for application in the Iberian Peninsula than the data used in the other relations, most of them from earthquakes in the USA. Another difference with the NCSE-02 map is the inclusion of the Mula and Bullas earthquakes in the hazard evaluation and, therefore, in the new map

\section{Conclusion}

The 1911 March earthquake was the largest shock that has occurred in the Murcia region in the last 100 years, with maximum intensity of VII-VIII and magnitude of 5.7. The most recent earthquakes of Mula (1999) and Bullas (2002) have intensities of VI-VII and V, respectively, and magnitudes of 5.3 and 5.2. The Mula shock is probably associated with the Crevillente fault, with reverse faulting along a $4 \mathrm{~km}$ section. Focal mechanisms for the Mula and Bullas events give subhorizontal pressure axes oriented from northwestsoutheast to north-south, in agreement with the general stress pattern for Iberia. STF obtained for the 1999 and 2002 events correspond to a simple rupture process of duration $0.1 \mathrm{sec}$. These motions agree with the character of the Crevillente fault; but for the Bullas earthquakes this is less clear, because their epicenters are located $3 \mathrm{~km}$ to the south of the Crevillente fault. The stress pattern derived from focal mechanisms of the Mula and Bullas earthquakes gives subhorizontal compression in a north-south direction in the Mula region, and northwest-southeast in the Bullas region.

The strong motions recorded in Mula and Bullas shocks are quite low, with PGA values lower than $0.020 \mathrm{~g}$. The PGA empirically estimated for both shocks in the epicentral area is $0.10-0.15 \mathrm{~g}$ for an $M_{\mathrm{w}} 4.8$ earthquake. The seismic hazard map gives PGA values for a return period of 475 years in the Murcia region that are higher than those proposed in the Spanish Building Code NCSE-02 map. The strong motions recorded for the Mula and Bullas earthquakes are, in general, lower than the ones predicted on the building code map and also than the ones resulting from our study. The seismic hazard in the region is actually higher than that corresponding to just these earthquakes.

\section{Acknowledgments}

The authors wish to thank the Instituto Geográfico Nacional (Madrid, Spain) for providing part of the data. Dr. Martínez Solares and C. López Moreno from IGN helped both with plotting the intensity maps and with the discussion about the hypocenters. We thank Prof. A. Udías (UCM, Spain) and Dr. L. Drake, former director of San Calixto Observatory (La Paz, Bolivia), who helped us to substantially improve the manuscript. This work has been supported in part by the Ministerio de Ciencia y Tecnología (Spain), projects REN2000-0777-C02-01 and REN2003-05178-C03-01.

\section{References}

Ambraseys, N. N., K. A. Simpson, and J. J. Bommer (1996). Prediction of horizontal response spectra in Europe, Earthq. Engin. Str. Dyn. 25, $371-400$.

Badal, J., E. Samardjieva, and G. Payo (2000). Moment magnitudes for early instrumental Iberian earthquakes, Bull. Seism. Soc. Am. 90, $1161-1173$.

Batlló, J. (2000). Catálogo-Inventario de Instrumentos Antiguos, Instituto Geográfico Nacional, Madrid (in Spanish).

Brillinger, D. R., A. Udías, and B. A. Bolt (1980). A probability model for regional focal mechanism solution, Bull. Seism. Soc. Am. 78, 2008 2224.

Brune, J. (1970). Tectonic stress and the spectra of seismic shear waves form earthquakes, J. Geophys. Res. 75, 4997-5009.

Buforn, E., and C. Sanz de Galdeano (2001). Focal mechanism of Mula (Murcia, Spain) earthquake of 2 February 1999, J. Seism. 5, 277-280.

Buforn, E., A. Udías, and R. Madariaga (1991). Intermediate and deep earthquakes in Spain, Pure Appl. Geophys. 136, 375-393.

Buforn, E., A. Udías, and J. Mézcua (1988). Seismicity and focal mechanisms in south Spain, Bull. Seism. Soc. Am. 78, 2008-2024.

Buforn, E., M. Bezzeghoud, A. Udías, and C. Pro (2004). Seismic sources on the Iberia-African plate boundary and their tectonic implications, Pure Appl. Geophys. 161, 623-646.

Buforn, E., P. Coca, A. Udías, and C. Lasa (1997). Source mechanism of intermediate and deep earthquakes in southern Spain, J. Seism. 1, $113-130$.

Buforn, E., J. Martín Dávila, G. Bock, A. Pazos, A. Udías, and W. Hanka (2002). TEDESE Project, European Geophysical Society, Nice 2002.

Cornell, C. A., 1969. Engineering seismic risk analysis, Bull. Seism. Soc. Am. 58, 1583-1606.

Dañobeitia, J. J., V. Sallares, and J. Gallart (1998). Local earthquakes seismic tomography in the Betic Cordillera (Southern Spain), Tectonophys. 160, 225-239.

Galbís, J. V. (1932) Catálogo Sísmico de la Zona Comprendidad entre los Meridianos $5^{\circ} \mathrm{E}$ y $20^{\circ} \mathrm{W}$ de Greenwich y los Paralelos $45^{\circ} \mathrm{N}$ y $25^{\circ} \mathrm{N}$ I, Instituto Geográfico, Catastral y de Estadística, Madrid, 567-569 (in Spanish).

IGN (1999). Serie sísmica de Mula (Murcia). Segundo Informe General, Subdirección General de Geodesia y Geofisica, Instituto Geográfico Nacional, Madrid, 35 pp. (in Spanish).

Jimenez de Cisneros, D. (1911). Boletín de la Real Sociedad Española de Historia Natural XI, 210-211.

Klein, F. (2000). Hypocenter location program HYPOINVERSE. Users Guide to Version 2000, U.S. Geol. Surv. Open-File Rep., version 0.99.

Mancilla, F. L., C. Ammon, R. Herrmann, and J. Morales (2002). Faulting parameters of the 1999 Mula earthquake, southeastern Spain, Tectonophysics 354, 139-155.

Martínez-Diaz, J. J., A. Rigo, L. Louis, R. Capote, J. L. Hernandez-Henrile, E. Carreño, and M. Tsige (2002). Caracterización geológica y sismotectónica del terremoto de Mula (Febrero 1999, $M_{\mathrm{b}}$ 4.8) mediante la utilización de datos geológicos, sismológicos y de interferometría de RADAR (INSAR), Geogaceta 31, 157-160 (in Spanish).

Margottini, C., D. Molin, B. Narcisi, and L. Serva (1989). Intensity vs. acceleration: Italian data, Proc. Workshop Historical Seismicity of Central-Eastern Mediterranean Region, C. Margottini and L. Serva, (Editors), ENEA, Casaccia, Rome.

McGuire, R. K. (1976). EQRISK; Evaluation of earthquake risk to site, U.S. Geol. Surv. Open-File Rep. 76-67, 90 pp.

Medvedev, S. V., and V. Sponheuer (1969). Scale of seismic intensity, Proc. of the 4th World Conf. on Earthquake Engineering, Santiago, Chile.

Mézcua, J., and J. M. Martínez Solares (1983). Sismicidad del área IberoMogrebí, Instituto Geográfico Nacional, Madrid (in Spanish).

Morales, J., I. Serrano, A. Jabaloy, J. Galindo-Zaldivar, D. Zhao, F. Torcal, F. Vidal, and F. Gonzalez-Lodeiro (1999). Active continental sub- 
duction beneath the Betic Cordillera and the Alboran Sea, Geology 27, 735-738.

Mori, J., and A. Frankel (1990). Source parameters for small events associated with the 1986 North Palm Springs, California, earthquake determined using empirical Green functions, Bull. Seism. Soc. Am. 80, 278-285.

Muñoz, D., A. Udías, and E. Moreno (1984). Reevaluación de los datos del terremoto de 1829 (Torrevieja), Sismicidad Histórica de la Región de la Peninsula Ibérica, Publicación de la Asociación Española de Ingeniería Sísmica, Madrid, 38-41 (in Spanish).

Muñoz, D., and A. Udías (1991). Three large historical earthquakes in southern Spain, in Seismicity, Seismotectonics and Seismic Risk of the Ibero-Maghrebian Region, Instituto Geográfico Nacional, Madrid, 175-182.

Rey Pastor, A. (1936). Sismicidad de las regiones litorales españolas del Mediterráneo: II Región Bética y Subbética, Géologie des chaines Betique et Subbetique IV: 1, 20-22 (in Spanish).

Rey Pastor, A. (1949). Comarca sísmica de Caravaca y el sismo del 23 de junio de 1948, Instituto Geográfico y Catastral, Madrid, 21-33 (in Spanish).

Rueda, F., J. Mézcua, and M. Sánchez Ramos (1984). La serie sísmica de Adra (Almería) de 1993-1994 y sus principales consecuencias sismotectónicas, Avances en Geofísica y Geodesia, Instituto Geográfico Nacional, Madrid, 91-98.

Sabetta, F., and A. Pugliese (1996). Estimation of response spectra and simulation of nonstationary earthquake ground motions, Bull. Seism. Soc. Am. 86, 337-352.

Sánchez Lozano, R., and A. Marín (1912). Estudio relativo a los terremotos ocurridos en la provincia de Murcia en 1911, Bol. Inst. Geológico, Madrid XII, 179-214 (in Spanish).

Sánchez Navarro-Neumann, M. M. (1911). Los recientes terremotos murcianos, Revista de la Sociedad Astronómica de España, 119-122 (in Spanish).

Sánchez Navarro-Neumann, M. M. (1912). Enumeración de los terremotos sentidos en España durante el año 1911, Boletín Real Soc. Española Historia Natural, 512-518 (in Spanish).

Sánchez Navarro-Neumann, M. M. (1917). Ensayo sobre la sismicidad del suelo español, Boletín Real Soc. Española Historia Natural, 100-101 (in Spanish).

Sánchez Navarro-Neumann, M. M. (1920). Bosquejo sísmico de la Península Ibérica, in La Estación Sismológica y el Observatorio Astronómico de Cartuja, Granada, 43-45 (in Spanish).

Sanz de Galdeano, C. (1983). Los accidentes y fracturas principales de las Cordilleras Béticas, Estudios Geológicos 39, 157-165 (in Spanish).

Spanish Building Code NCSE-02 (2002). "Norma de la Construcción Sismorresistente Española," Real Decreto 997/2002, de 27 de septiembre, por el que se aprueba la norma de construcción sismorresistente: parte general y edificación (NCSR-02), Boletín Oficial del Estado, 244, 35,898-35,967 (in Spanish).

Stich, D., C. Ammon, and J. Morales (2003). Moment tensor solutions for small and moderate earthquakes in the Ibero-Maghreb region, J. Geophys. Res. 108, no. B3, 2148, doi 10.1029/2002JB002057.

Tento, A. L., L. Franceschina, and A. Marcellini (1992). Expected ground motion evaluation for Italian sites, Proc. Tenth World Conf. Earthq., Madrid 1, 489-494.

Tordesillas, J. M., M. López-Muga, E. Carreño, C. López-Moreno, J. Martinez-Días, R. Capote, L. Castro, and M. Tsige (2003). Interferometría de RADAR (INSAR) y su aplicación a la sismotectónica, Instituto Geográfico Nacional, Madrid.

\section{Appendix \\ 1. Newspapers (Madrid)}

- ABC: 22 March 1911; 26 March 1911; 4 April 1911.

- El Heraldo de Madrid: 4 April 1911, 5 April 1911.

- El Liberal: 22 March 1911; 4 April 1911; 5 April 1911;

6 April 1911; 7 April 1911; 20 April 1911.

- El Tiempo: 7 April 1911; 12 April 1911.

- La Epoca: 22 March 1911; 26 March 1911; 3 April 1911.

\section{Acts and Records of Town Halls}

- Lorquí: 8 April 1911

- Ceutí: 16 April 1911

- Alguazas: 7 May 1911; 31 May 1911

- Murcia: 7 April 1911; 28 April 1911.

\section{Other Information (Lorquí Hall)}

- List of private and public buildings damaged by the earthquake of 3 April 1911.

- List of earthquakes in Lorquí from 21 March to 20 May 1911.

- File of request to government for funds. Response of the government with support of 20,000 pts to help the affected people. Distribution of the funds to poor people affected by the earthquakes

Departmento de Geofísica y Meteorología

Facultad de CC. Físicas

Universidad Complutense

28040 Madrid, Spain

ebufornp@fis.ucm.es, cfresno@fis.ucm.es,

domuso@fis.ucm.es, irodrigu@fis.ucm.es

(E.B., C.F., D.M., I.R.)

Escuela Universitaria de Ingeniería Topográfica

Campus SUR UPM

Ctra Valencia km 7

28031 Madrid, Spain

ma_ben@euitto@upm.es

(B.B.)

Instituto Andaluz de Ciencias de la Tierra

CSIC-Universidad de Granada

Facultad de Ciencias

Universidad de Granada

18071 Granada, Spain

csanz@ugr.es

(C.S.) 